\title{
Cryopreservation of Tropical Plant Germplasm with Vegetative Propagation - Review of Sugarcane (Saccharum spp.) and Pineapple (Ananas comusus (L.) Merrill) Cases
}

\author{
Marcos Edel Martinez-Montero ${ }^{1}$, Maria Teresa Gonzalez Arnao ${ }^{2}$ and \\ Florent Engelmann ${ }^{3,4}$ \\ ${ }^{1}$ University of Ciego de Avila/Bioplantas Centre \\ ${ }^{2}$ Universidad Veracruzana, \\ ${ }^{3} I R D$, UMR DIAPC \\ ${ }^{4}$ Bioversity International \\ ${ }^{1} \mathrm{Cuba}$ \\ ${ }^{2}$ Mexico \\ ${ }^{3}$ France \\ ${ }^{4}$ Italy
}

\section{Introduction}

Sugarcane (Saccharum sp. hybrids) is a crop of major importance, which is cultivated on a large scale in tropical and subtropical regions primarily for its high sucrose content. Cultivated pineapple (Ananas comosus (L.) Merrill, which is now called Ananas comosus var comosus) belongs to the family Bromeliaceae. It is economically the fourth most important crop worldwide in terms of tropical fruit production and follows banana, mangoes and citrus. One of the main drawbacks faced by sugarcane and pineapple agriculture worldwide is the vegetative (i.e. asexual) nature of its conventional propagation. The consequence is that plants in the field must be replaced at intervals ranging from 1 to 5 years, a process that is costly, tedious and time-consuming. Furthermore, if the planting material is of low quality, yields decrease and more tillage is needed. The crops are exposed to natural disasters, while the propagation system leads to systemic disease transmission, and natural selection and plagues also take their toll. Moreover, the industry is in dramatic need of planting material, which cannot be produced in sufficient quantities to meet the demand using classical macropropagation techniques.

In vitro culture techniques have been extensively developed and applied for several thousand plant species including sugarcane and pineapple. Their uses are of high interest for multiplication, conservation and transformation of plant germplasm. Indeed, they allow the multiplication of plant material with high multiplication rates in an aseptic environment, reduction of space requirements, genetic erosion is reduced under optimal storage conditions, and minimized of the expenses in labour costs. Moreover, tissue culture systems 
greatly facilitate the international exchange of germplasm as the size of the samples is drastically diminished and they can be shipped in sterile conditions. Different in vitro conservation methods are employed, depending on the storage duration requested. For short- and medium-term storage, the aim is to reduce growth and to increase the intervals between subcultures. For long-term storage, cryopreservation, i.e. storage at ultra-low temperature, usually that of liquid nitrogen $\left(-196^{\circ} \mathrm{C}\right)$, is the only current method ensuring long-term storage of germplasm from vegetatively propagated species. At this temperature, all cellular divisions and metabolic processes are stopped; therefore, plant material can thus be maintained without alteration or modification. Moreover, cultures are stored in a small volume, protected from contamination, requiring very limited maintenance.

This Chapter comprises two main sections focusing on the establishment, optimization and application of cryopreservation techniques to different tissues of in vitro sugarcane and pineapple cultures. The first part presents the cryopreservation protocols developed for sugarcane apices isolated from in vitro grown plants, embryogenic calluses and somatic embryos, as well as some analytical techniques (electrolyte leakage, protein content and lipid peroxidation products), used to describe the impact of the successive steps of the protocol on the physiological state of the cultures, which are also useful to refine the cryopreservation protocol. The effect of cryopreservation on the phenotypical development, both in vitro and in the field, of sugarcane plants regenerated material will be also presented. The second section presents the studies performed to set up and refine a cryopreservation protocol for apices of pineapple in vitro plantlets. The protocol established following the vitrification approach was successfully applied for the first time to shoot tips of three pineapple varieties, and then extended to nine pineapple accessions belonging to the in vitro collection of Bioplantas Centre in Cuba. In addition, we present the preliminary assays developed using callus of two pineapple cultivars. In the conclusion, we discuss the possibilities and prospects of utilisation of cryopreservation techniques for the long-term storage of other vegetatively propagated tropical plant species.

\section{Cryopreservation protocols for sugarcane}

Several review papers have been published, which provide lists of species which have been successfully cryopreserved (Cyr, 2000; Engelmann, 1997; Engelmann \& Takagi, 2000; Sakai et al., 2002). For vegetatively propagated species, cryopreservation has a wide applicability in terms of species coverage, since protocols have been successfully established for roots and tubers, fruit trees, ornamentals, forestry species and plantation crops from both temperate and tropical origin (Engelmann, 2004; Kaczmarczyk et al., 2008; Engelmann, 2010; Engelmann, 2011).

In the case of sugarcane, cryopreservation protocols have been developed for various materials: apices of in vitro plantlets using the encapsulation-dehydration technique (Gonzalez-Arnao et al., 1993; Paulet et al., 1993); cell suspensions (Finkle \& Ulrich, 1979; Gnanapragasam \& Vasil, 1990) and embryogenic callus using classical freezing protocols (Eksomtramage et al., 1992; Gnanapragasam \& Vasil, 1992; Jian et al., 1987) and simplified cryopreservation protocols (Martinez-Montero et al., 1998). Recently, it was published the cryopreservation procedure based on vitrification techniques for somatic embryos (Martinez-Montero et al., 2008). 


\subsection{Cell suspensions}

The first experimental research on sugarcane cell suspension was accomplished the end of 1970 and at the beginning of 1980 decades (Finkle \& Ulrich, 1979; Finkle \& Ulrich, 1982; Ulrich et al., 1979; Ulrich et al., 1984). These authors demonstrated that resistance of cells to freezing to $-23^{\circ} \mathrm{C}$ and $-40^{\circ} \mathrm{C}$ was possible with little decrease in survival by using mixtures of glucose, dimethylsulfoxide and polyethylene glycol as cryoprotectants. However, no plants were recovered from the cryopreserved cell suspension.

Later on, Gnanapragasam \& Vasil (1990) reported that efficient plant regeneration was obtained from a cryopreserved embryogenic cell suspension of one commercial sugarcane hybrid established from leaf derived callus. They observed pregrowing the cells for three days in Murashige \& Skoog (1962) basal medium supplemented with $0.33 \mathrm{M}$ sorbitol was essential to the process. A regeneration efficiency of $92 \%$ was obtained and plants regenerated from cryopreserved cells, and grown to maturity in the greenhouse, were morphologically identical to regenerated control plants. Later, there were not detected differences at molecular level using RFLP technique comparing plants regenerated from cryopreserved and control cells for three sugarcane hybrids (Chowdhury \& Vasil, 1993).

\subsection{Embryogenic callus}

The first success for cryopreservation of sugarcane embryogenic callus was obtained by Ulrich et al., (1979) for the hybrid H50-7209. It was a pretreatment using a combination of $10 \%$ polyethylene glycol, $8 \%$ glucose and $10 \% \mathrm{DMSO}$, freezing rate of $2^{\circ} \mathrm{C} \cdot \mathrm{min}^{-1}$ until a first transfer temperature of $-40^{\circ} \mathrm{C}$ and freezing rate of $5^{\circ} \mathrm{C} \cdot \mathrm{min}^{-1}$ until second transfer temperature of $-80^{\circ} \mathrm{C}$. However, the recovery of cryopreserved callus was achieved only with root regeneration. Ulrich et al., (1984) obtained after modifications of the same protocol a limited number of albino plantlets from cryopreserved calluses.

Later on, high survival rates (ca. 90\%) and recovery of whole plants were obtained by Jian et al., (1987), Eksomtramage et al., (1992) and Gnanapragasam \& Vasil (1992). The conditions defined were different from that used by Ulrich et al., $(1979,1984)$. For cryoprotective treatment, a mixture of sorbitol and DMSO was used by Jian et al., (1987) and Gnanapragasam \& Vasil (1992); Eksomtramage et al., (1992) employed a mixture of sucrose and DMSO. Freezing conditions were also different: $1^{\circ} \mathrm{C} \cdot \mathrm{min}^{-1}$ from $0^{\circ} \mathrm{C}$ to $-10^{\circ} \mathrm{C}$, and kept for $15 \mathrm{~min}$ at the same freezing rate from $-10^{\circ} \mathrm{C}$ down to $-40^{\circ} \mathrm{C}$ and kept for $1-5 \mathrm{~h}$, and finally immersed into liquid nitrogen (Jian et al., 1987); or $0.5^{\circ} \mathrm{C} \cdot \mathrm{min}^{-1}$ down to $-40^{\circ} \mathrm{C}$ or $-45^{\circ} \mathrm{C}$ with no plateau at the end of the controlled freezing sequence (Eksomtramage et al., 1992 and Gnanapragasam \& Vasil, 1992). Moreover, the technique developed by Eksomtramage et al., (1992) was successfully applied to calluses of 10 varieties.

These authors have followed the strategy known as dehydration by extracellular freezing, which uses a controlled freezing regime (Withers \& King, 1980). However, this procedure requires expensive and sometimes complex programmable freezing devices, limiting its use to laboratories specializing in cryopreservation (Ashmore, 1997; Reed, 2001). Furthermore, their research has been focused on the cryopreservation of sugarcane calli obtained from segments of immature leaves belonging to in vitro cultured plants; however, such explants are known to have a limited morphogenetic capacity (Krishnaraj \& Vasil, 1995) and it is widely acknowledged that immature embryos, as well as young inflorescences, are 
physiologically better explants for calli production because they retain their embryogenic capacities (Merkle et al., 1995).

\subsubsection{Optimization of methodology for sugarcane callus}

Our research team (Martinez-Montero et al., 1998, 2006), using the cryo-research for sugarcane callus described above as starting point, published the results for establishing step by step a methodology for the cryopreservation of sugarcane calli with embryogenic structures obtained from immature inflorescence (Figure 1). We optimized the following aspects according to the in vitro survival and regeneration (plants per $500 \mathrm{mg}$ of calli) percentages for: Selection of the cooling procedure, the effect of the cooling procedure and of the type of alcohol, the effect of the induction time of extracellular ice crystals, the effect of post-subculture time, the effect of sucrose and dimethylsulfoxide concentration in the cryoprotective medium, and the effect of the pre-freezing time.

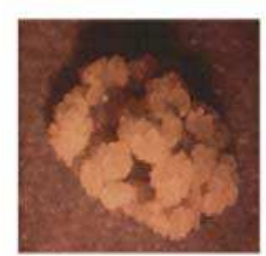

(i) Selection of material

15 days post-subculture

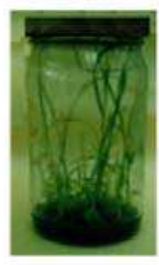

(vii) Regeneration

( 35 days)

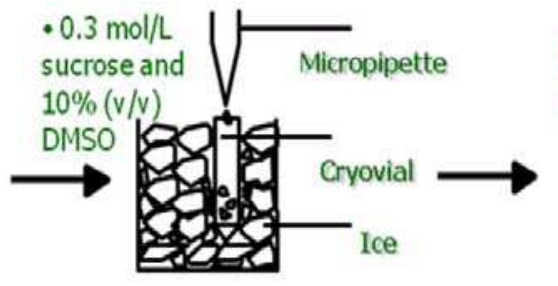

(ii) Cryo-protection (1 h)

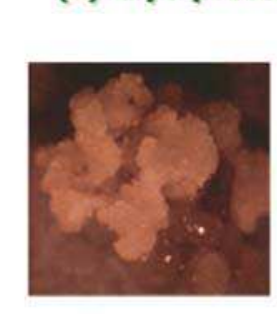

(vi) Recovery - Dark (40 days)

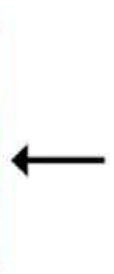

(v) Thawing - Rapid at $+40^{\circ} \mathrm{C}$
- Temp, induction: $-7.5^{\circ} \mathrm{C}$

- Time induction: $5 \mathrm{~s}$

- Time pre-freezing.: 2 hours

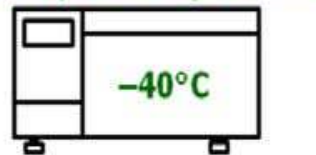

(iii) Cooling procedure

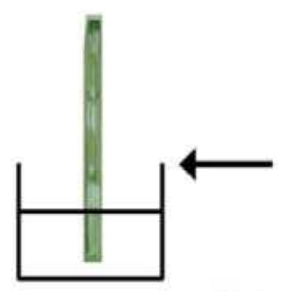

(iv) Storage at $196^{\circ} \mathrm{C}$

- 16 months

Fig. 1. Optimized methodology for the cryopreservation of sugarcane calli with embryogenic structures.

Firstly, we based on the results carried out by Maddox et al. (1983) and Withers (1985) who successfully used uncomplicated freezing procedures for cellular suspensions of Nicotiana and Musa, respectively (Figure 2). We evaluated the application of one of these devices as an alternative to establish techniques for the cryopreservation of sugarcane calli with embryogenic structures (i.e., cooling rate controlled by a computer-coupled programmable freezer).

As results was detected a survival after storage in liquid nitrogen for both cooling procedures implying the existence of a protective dehydration process that allows the vitrification of some cells without the formation of intracellular ice crystals. However, from 
a practical point of view, seeding ice crystals is much more difficult when using the procedure proposed by Maddox et al., (1983).

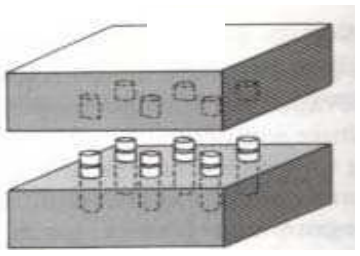

a

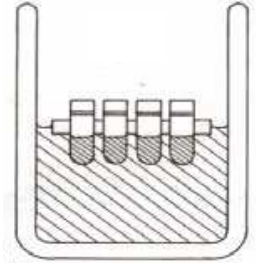

b

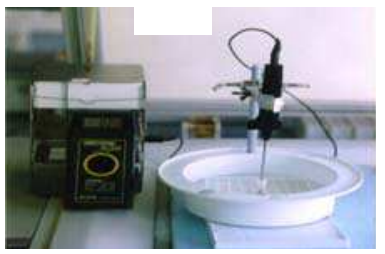

C

Fig. 2. Devices used by Maddox et al. (1983) (A), Withers (1985) (B) and our research group (C) for the establishment of cryopreservation procedures.

In general, the "classical" cryopreservation protocols provide insufficient detail on seeding ice crystals step (Martinez-Montero et al., 2006). For instance, although the analysis of this parameter must have been unavoidable for the development of the protocols of Jian et al., (1987) and Gnanapragasam \& Vasil (1992), these analyses are not described in their articles; and even Eksomtramage et al., (1992), who first mentioned the need for this step when freeze sugarcane calli, provide little detail on its implementation.

Optimizing the effect of post-subculture time on the survival and regeneration of plants from cryopreserved calli the results reported by Jian et al., (1987) and Martinez-Montero et al., (2006) coincided. We founded that survival after cryopreservation is associated with the selection step during the post-subculture period, reaching a maximum at 15 days postsubculture. Moreover, we correlated this finding to the physiological state of the calli before cryopreservation and measured the growth of the calli. These results are the basis for a rational selection of the material to be cryopreserved, since several authors have shown that there is a correlation for different species between the phase of active growth of the calli and its performance upon cryopreservation (Reinhoud et al., 2000; Withers, 1985; Yoshida et al., 1993). It has been proven that the morphology of the cultured cells has a marked influence on cryotolerance. In most species, only small cells with a highly dense cytoplasm, usually found in small cellular aggregates in the periphery of the callus, survive after cryopreservation; whereas large, vacuolated cells are damaged during freezing (Kristensen et al., 1994; Withers, 1985).

We also founded the decrease in survival and regeneration when using sucrose concentrations higher than $0.3 \mathrm{M}$. The importance of sucrose tolerance within this setting is determined by the role of this disaccharide in the regulation of the hydric potential of the cells (Tetteroo, 1996); sucrose has also occasionally been considered an inducer of cellular division and differentiation (Feher, 2003). Furthermore, there is evidence suggesting that sucrose functions as a genetic regulatory signal for genes coding for enzymes and proteins involved in transport and storage (Lunn \& MacRae, 2003). Additionally, Ausborn et al., (1994) and Turner et al., (2001) detected that sucrose stabilizes the lipid bilayers on the membranes by forming disaccharide-lipid hydrogen bonds, whereas Niu et al., (1997) 
founded that the right amount of intracellular sucrose can protect a number of enzymes from ion-mediated toxicity.

According to our results, the sugarcane calli did not survive the cryopreservation procedure when dimethylsulfoxide was omitted from the cryoprotective mixture; and both the survival and plant regeneration percentages rose steadily with increasing dimethylsulfoxide concentrations, up to $10 \%$. However, in clear contrast with the results obtained when testing different amounts of sucrose, there are no differences in survival between the cryopreserved and non-cryopreserved samples at concentrations higher than the optimum $(10 \% \mathrm{v} / \mathrm{v}$ in this case), and the contrast is even starker when comparing plant regeneration rates, where the cryopreserved material performs even better than the non-cryopreserved calli. These results agree with those of Finkle et al., (1985) for rice cells, who concluded that the effects achieved by using dimethylsulfoxide are paradoxical, since although this substance is clearly toxic, but inhibits the growth of ice crystals during cryopreservation.

Our data obtained during the experiment for dimethylsulfoxide tolerance are coherent with the reports for other biological systems, associated to the high degree of toxicity of dimethylsulfoxide (Arakawa et al., 1990; Fahy et al., 1990). Kartha et al., (1988) detected that dimethylsulfoxide produces an inhibition of 35 to $42 \%$ on the growth of embryogenic cultures of white spruce when used at a concentration higher than $5 \%(\mathrm{v} / \mathrm{v})$, and Klimaszewska et al., (1992) reported a $28 \%$ reduction in the growth of embryogenic tissues from black spruce when treated with $15 \%(\mathrm{v} / \mathrm{v})$ dimethylsulfoxide; this effect, according to the microscopic observations of these authors, is due to the induction by this substance of a strong plasmolytic effect at the cellular level.

However, and in spite of these findings, dimethylsulfoxide has been, and still is used as a cryoprotectant during storage at ultra-low temperatures. According to Engelmann, (2000) this apparent paradox is due to the fact that dimethylsulfoxide is always used as part of a cryoprotective mixture, rather than individually. Arakawa et al., (19990) have provided evidence that the toxicity of dimethylsulfoxide in isolated proteins is mediated by hydrophobic interactions, which are favored at increasing temperatures; in this context, this effect is minimized by the use, during preculture, of sucrose at $0^{\circ} \mathrm{C}$, which induces the biosynthesis of proteins that neutralize the toxic effects of this agent (caused by its interaction mainly with lysine residues) (Anchordoguy et al., 1991; Klimazewska et al., 1990; Swan et al., 1999).

Although the exact cryoprotective mechanism of dimethylsulfoxide at ultra-low temperatures remains unknown, it is widely acknowledged that it depends on the colligative properties of this penetrating compound; that is, dimethylsulfoxide affects the formation of ice crystals by decreasing the equilibrium freezing point of the solution, in direct dependence on its molar concentration (Kinoshita et al., 2001; McGann, L.E. \& Walterson, 1987). Dimethylsulfoxide, as a cell-penetrating agent, also decreases the intracellular concentration of toxic electrolytes on unfrozen cells (Finkle et al., 1985).

Anchordoguy et al., (1991) suggested, furthermore, that there is another, not colligative mechanism for dimethylsulfoxide-mediated cryoprotection, which involves ionic interactions between the oxygen atom from this molecule and phospholipid bilayers. Such a mechanism would stabilize the cell membranes during the freeze-thaw cycle. The findings by us related wit better plant regeneration percentages from cryopreserved calli as compared to calli which had not been cryopreserved could be similar to those of Aronen et 
al., (1999) in embryogenic cultures of Abies cephalonica. We later founded that the storage in liquid nitrogen eliminates a high proportion of cells which had been previously damaged by dimethylsulfoxide, since only small, meristematic cells survive this treatment. Furthermore, the use of cryoprotective mixtures containing other agents greatly minimizes the inherent toxicity of dimethylsulfoxide.

On the other hand, it is recognized that the process of apoptosis (programmed cell death) is not circumscribed to animals, but also occurs in plants, where it is used for the selective elimination and suicide of unwanted cells (Krishnamurthy et al., 2000). According to Joyce et al., (2003), among the cells undergoing this process are those which have sustained high levels of in vitro stress, which can compromise their physiology. Such a mechanism might, therefore, be involved in dimethylsulfoxide-mediated toxicity.

After using the simple freezing procedure proposed by Martinez-Montero et al. (1998), it was determined that, apparently, the best dehydration levels are reached by the sugarcane calli when kept for 2 or 3 hours at $-40{ }^{\circ} \mathrm{C}$. It should be noted that the survival percentages achieved in this study were comparable to the best values obtained by Jian et al., (1987) and Eksomtramage et al., (1992). Survival rates did not increase with longer pre-freezing times, probably due to excessive dehydration of the material. Studies based on the use of nuclear magnetic resonance spectroscopy in Catharanthus roseus cells (Chen et al., 1984), vegetative apple buds (Tyler et al., 1988) and different tissues from Rhododendron japonicum (Ishikawa et al., 2000) have determined that the optimum pre-freezing time for a specified pre-freezing temperature depends on the amount of water still remaining inside the cells. Tyler et al., (1988) proved the need for the pre-freezing step when they showed that the incubation of samples at an intermediate negative temperature before immersion in liquid nitrogen would result in a better performance of the cryopreserved material after thawing.

Finally, the optimized protocol carried out by our team took into account the in vitro survival and regeneration (plants per $500 \mathrm{mg}$ of sugarcane calli) percentages and was validated for: a) three varieties (CP52-43, C1051-73, C91-301) (Table 1) ; b) explants obtained either from immature inflorescences or immature leaves from in vitro plants; $\mathrm{c}$ ) calli stored for up to 16 months under liquid nitrogen, belonging to the CP52-43 variety (Table 2).

\begin{tabular}{|c|c|c|c|}
\hline \multicolumn{2}{|c|}{ Variety } & $\begin{array}{c}\text { Survival } \\
(\%)\end{array}$ & $\begin{array}{c}\text { Regeneration } \\
\text { (plants per 500mg of calluses) }\end{array}$ \\
\hline \multirow{3}{*}{$-\mathrm{LN}$} & CP52-43 & $98,8 \mathrm{a}$ & $230 \mathrm{a}$ \\
\cline { 2 - 4 } & C91-301 & $69,5 \mathrm{c}$ & $72 \mathrm{c}$ \\
\cline { 2 - 4 } & C1051-73 & $44,1 \mathrm{~d}$ & $55 \mathrm{~d}$ \\
\hline \multirow{2}{*}{$+\mathrm{LN}$} & CP52-43 & $89,0 \mathrm{~b}$ & $150 \mathrm{~b}$ \\
\cline { 2 - 4 } & C91-301 & $38,8 \mathrm{~d}$ & $42 \mathrm{e}$ \\
\cline { 2 - 4 } & C1051-73 & $22,2 \mathrm{e}$ & $25 \mathrm{f}$ \\
\hline \multicolumn{2}{|c|}{ Typical Error } & 0,190 & 1,421 \\
\hline
\end{tabular}

Table 1. Effects of optimized cryopreservation protocol on survival and plant regeneration produced from control (-LN) and cryopreserved (+LN) sugarcane embryogenic calluses (varieties CP52-43, C91-301 and C1051-73). Means within columns followed by the same letter are not significantly different (ANOVA $p<0,05$ Tukey,). Data were transformed for statistical analysis in accordance with $x^{\prime}=2$ arcsine $\left((x / 100)^{0,5}\right)$ and with $x^{\prime}=(0,5+x)^{0,5}$ for percentage of survival and plant regeneration, respectively. 


\begin{tabular}{|c|c|c|c|c|}
\hline & $\begin{array}{c}\text { Time } \\
\text { (months) }\end{array}$ & Survival (\%) & $\begin{array}{c}\text { Calluses that regenerated } \\
\text { plants }(\%)\end{array}$ & $\begin{array}{c}\text { Regeneration } \\
\text { (plants per } 500 \mathrm{mg} \text { of } \\
\text { calluses) }\end{array}$ \\
\hline \multirow{5}{*}{-NL } & 1 & $100 \mathrm{a}$ & $100,0 \mathrm{a}$ & $225,2 \mathrm{a}$ \\
\hline & 4 & $98,6 \mathrm{a}$ & $100,0 \mathrm{a}$ & 224,3 a \\
\hline & 8 & $96,7 \mathrm{ab}$ & $66,7 \mathrm{~b}$ & $77,0 \mathrm{c}$ \\
\hline & 12 & $97,5 \mathrm{ab}$ & $7,1 \mathrm{c}$ & $19,1 \mathrm{~d}$ \\
\hline & 16 & $11,5 \mathrm{c}$ & $0,0 \mathrm{~d}$ & $0,0 \mathrm{e}$ \\
\hline \multirow{5}{*}{$+\mathrm{NL}$} & 1 & $90,6 \mathrm{~b}$ & 96,7 a & $149,3 \mathrm{~b}$ \\
\hline & 4 & $87,6 \mathrm{~b}$ & 97,8 a & $142,9 \mathrm{~b}$ \\
\hline & 8 & $88,0 \mathrm{~b}$ & $93,3 \mathrm{a}$ & $135,1 \mathrm{~b}$ \\
\hline & 12 & $86,4 \mathrm{~b}$ & 97,0 a & $141,7 \mathrm{~b}$ \\
\hline & 16 & $90,0 \mathrm{~b}$ & 97,5 a & $140,3 \mathrm{~b}$ \\
\hline \multicolumn{2}{|c|}{ Typical Error } & 0,189 & 0,253 & 1,312 \\
\hline
\end{tabular}

Table 2. Effect of extended storage duration on the survival and plantlet produced from control (-LN) and cryopreserved (+LN) sugarcane embryogenic calluses (variety CP52-43). Means within columns followed by the same letter are not significantly different (ANOVA $p<0,05$ Tukey, $)$. Data were transformed for statistical analysis in accordance with $x^{\prime}=2$ arcsine $((x / 100) 0,5)$ and with $x^{\prime}=(0,5+x)^{0,5}$ for percentage of survival and plant regeneration, respectively.

\subsection{Apices}

The first attempt to freeze sugarcane apices were carried out by the group of Bajaj et al., (1987) using apices from in vivo plants. This material was pretreated with a mixture of $5 \%$ $(\mathrm{v} / \mathrm{v})$ of each DMSO, sucrose and glycerol during $45 \mathrm{~min}$. Then the freezing was accomplished by rapid immersion in liquid nitrogen of samples. However, the apices recovery was very scarce and with only small callus formation without plant regeneration.

Later on, research for the development of a cryopreservation protocol for sugarcane apices was carried out in the framework of collaborative program involving IRD (Institut de recherche pour le développement, Montpellier, France), CIRAD (Centre de coopération internationale en recherche agronomique pour le développement, Montpellier, France), CNIC (Centro Nacional de Investigaciones Cientificas, Havana, Cuba), IPGRI (International Plant Genetic Resources Institute, Rome, Italy) and FAO (Food and Agriculture Organisation of the United Nations, Rome, Italy).

A cryopreservation process using encapsulation/dehydration was set up for apices sampled on in vitro plantlets of sugarcane by Paulet et al., (1993) in CIRAD, Montpellier, France. After dissection, apices were cultured for one day on standard medium and then encapsulated in 
medium with $3 \%$ alginate. Optimal conditions comprised preculture for $2 \mathrm{~d}$ in liquid medium with $0.75 \mathrm{M}$ sucrose, desiccation for $6 \mathrm{~h}$ under the laminar flow or for 10-11 hours with silicagel followed by rapid freezing and slow thawing. Survival after freezing in liquid nitrogen ranged between 38 and $91 \%$ for the 5 varieties experimented.

Later on, Gonzalez-Arnao et al. (1993) in CNIC, Havana Cuba investigated the effect of sucrose concentration during the pregrowth treatment and of freezing procedure on the survival of encapsulated apices of six sugarcane varieties. The optimal sucrose concentration was $0.75 \mathrm{M}$ during $24 \mathrm{~h}$. We showed that encapsulated apices of sugarcane could withstand freezing in liquid nitrogen using various freezing procedures. Growth recovery of apices after thawing was very rapid and direct, due to the fact that most cells of the apical region had been only slightly harmed, as revealed by histological examination.

Moreover, our group studied apices sampled on in vitro plantlets of different varieties and could be cryopreserved using the encapsulation-dehydration technique and stored for one year at the temperature of liquid nitrogen without modification in their recovery percentage (Gonzalez-Arnao et al., 1999). By contrast, apices placed at $-70^{\circ} \mathrm{C}$ or $-25^{\circ} \mathrm{C}$ lost viability very rapidly. There are several explanations for this result: even though vitrification of internal solutes has been observed during freezing of these materials, including sugarcane devitrification and recrystallization processes, which are detrimental to 'cellular integrity, take place at these temperatures (Gonzalez-Arnao et al., 1996). These contrasting results might be linked to the presence of higher levels of residual free water in the latter systems, which would recrystallize rapidly at these temperatures and result in the death of the explants. At lower temperatures comprised between -135 and -196 "C, no differences were noted in the regrowth capacity of all materials mentioned above whatever the storage duration tested.

It is interesting to note that, even though the two protocols set up were slightly different, the average results obtained on a total of 15 sugarcane varieties ( 8 frozen with the CNIC protocol, 7 with the CIRAD protocol) were similar (Table 3). It should also be noted that different varieties showed different sensitivities to preculture and desiccation, and to preculture, desiccation and freezing. However, there was only one case (Ja 60-5) where the difference between control and cryopreserved samples was very high, $70 \%$ and $24 \%$ survival, respectively. Both protocols are thus potentially applicable to a large range of varieties without any need for further adaptation.

Recently, in vitro shoot tips of two clones were successfully cryopreserved using encapsulation-dehydration according to Gonzalez-Arnao et al., (1993) and dropletvitrification with two vitrification solutions, PVS2 and PVS3 (Barraco et al., 2011). For both clones, encapsulation-dehydration induced significantly higher recovery, reaching $60 \%$ for clone H70-144 and 53\% for clone CP68-1026, compared with droplet-vitrification in which recovery was $33-37 \%$ for clone H70-144 and $20-27 \%$ for clone CP68-1026. Optimal conditions included preculture of encapsulated shoot apices for $24 \mathrm{~h}$ in liquid medium with $0.75 \mathrm{M}$ sucrose and dehydration with silica gel to $20 \%$ moisture content (fresh weight basis) before direct immersion in liquid nitrogen. With both protocols employed, regrowth of cryopreserved samples, as followed by visual observation, was always rapid and direct. 


\begin{tabular}{|c|c|c|}
\hline \multirow{2}{*}{ Variety } & \multicolumn{2}{|c|}{ Survival } \\
\cline { 2 - 3 } & -LN & +LN \\
\hline C 87-51 $\left(^{*}\right)$ & 90 & 80 \\
\hline C 266-70 $\left(^{*}\right)$ & 90 & 67 \\
\hline B 34104 $\left(^{*}\right)$ & 60 & 74 \\
\hline B 4362 $\left(^{*}\right)$ & 88 & 24 \\
\hline Ja 60-5 $\left(^{*}\right)$ & 70 & 38 \\
\hline IAC 5448 $\left(^{*}\right)$ & 50 & 60 \\
\hline POJ 2878 $\left(^{*}\right)$ & 56 & 60 \\
\hline CP 70-1133 $\left(^{*}\right)$ & 80 & 64 \\
\hline CP 68-1026 $\left(^{* *}\right)$ & 100 & 91 \\
\hline B 69566 $\left(^{* *}\right)$ & 100 & 64 \\
\hline Co 6415 $\left(^{* *}\right)$ & 80 & 38 \\
\hline Co 740 $\left(^{* *}\right)$ & 80 & 38 \\
\hline IAC 5118 $\left(^{* *}\right)$ & 50 & 75 \\
\hline My 5514 $\left(^{* *}\right)$ & 83 & 82 \\
\hline Q 90 $\left(^{* *}\right)$ & 100 & \\
\hline
\end{tabular}

Table 3. Survival of control (-LN) and cryopreserved (+LN) apices using the encapsulationdehydration technique according to the protocol described by GonzalezArnao et al. $\left(1993,{ }^{*}\right)$ and Paulet et al. $\left(1993,{ }^{* *}\right)$.

\subsection{Somatic embryos}

In Cuba, a micropropagation protocol based on the artificial seed technology has been established for sugarcane, which uses somatic embryos produced on semi-solid medium, an alternative which allows mass multiplication of plants from elite varieties (Nieves et al., 2001; Tapia et al., 1999). However, this protocol has an important limiting factor, which lies with the necessity of safely storing somatic embryos for the long-term (Benson, 2008). Establishing a cryopreservation protocol for somatic embryos would allow solving this problem.

In this sense our group (Martinez-Montero et al., 2008) compared three vitrification-based cryopreservation techniques, viz. vitrification, encapsulation-vitrification and dropletvitrification for cryopreserving sugarcane somatic embryos. No viability was achieved using the vitrification procedure. The comparison of the recovery pattern of cryopreserved somatic embryos showed that droplet-vitrification procedure was more efficient than encapsulation-vitrification (Table 1) based on the presence of green colour in somatic embryos and on the percentage of clumps with embryos converted into plants. Moreover, the presence of callus together with converted plants was observed with the encapsulationvitrification procedure. 


\begin{tabular}{|c|c|c|c|}
\hline Protocol & $\begin{array}{l}\text { Presence of } \\
\text { green colour in } \\
\text { SE (\%) }\end{array}$ & $\begin{array}{l}\text { Clumps } \\
\text { with SE } \\
\text { converted } \\
\text { into } \\
\text { plants } \\
(\%) \\
\end{array}$ & $\begin{array}{l}\text { Presence of } \\
\text { callus together } \\
\text { with converted } \\
\text { plants } \\
(\%)\end{array}$ \\
\hline $\begin{array}{l}\text { Encapsulation- } \\
\text { vitrification * }\end{array}$ & $8 b$ & $5 b$ & $67 \mathrm{a}$ \\
\hline $\begin{array}{l}\text { Droplet-vitrification }{ }^{\star * *} \\
\text { SEM }\end{array}$ & $\begin{array}{l}25 \mathrm{a} \\
0.22\end{array}$ & & \\
\hline \multicolumn{4}{|c|}{$\begin{array}{l}\text { Means with different letters are statistically different }(t \text {-test, } P<0.05) \text {. The } \\
\text { data were transformed before the analysis using } x^{\prime}=2 \text { arcsin }\left((x / 100)^{0,5}\right) \text {. } \\
\text { (Number of samples }=144) \text {. } \\
{ }^{*} \text {. The selected samples were encapsulated with } 3 \%(\mathrm{w} / \mathrm{v}) \mathrm{Na} \text {-alginate and } \\
\text { loading solution }(2 \mathrm{M} \text { glycerol }+0.4 \mathrm{M} \text { sucrose). The beads formed were } \\
\text { dehydrated at } 0^{\circ} \mathrm{C} \text { for } 10 \mathrm{~min} \text { in PVS2 before direct immersion in liquid } \\
\text { nitrogen. } \\
{ }^{* *} \text { The selected samples were loaded in } 2 \mathrm{M} \text { glycerol }+0.4 \mathrm{M} \text { sucrose for } 20 \\
\text { min at } 25^{\circ} \mathrm{C} \text {. Then, they were placed on the filter paper, transferred in } \\
\text { cryotubes and dehydrated at } 0^{\circ} \mathrm{C} \text { for } 80 \text { min with PVS2. The samples in } \\
\text { cryotubes were transferred in droplets of PVS2 solution }(10 \mu \mathrm{\mu l}) \text { placed on } \\
\text { aluminium foil strips and the strips were immersed in liquid nitrogen. }\end{array}$} \\
\hline
\end{tabular}

Table 4. Effect of the cryopreservation protocol on the recovery pattern of sugarcane somatic embryos (SE).

Untreated embryos were white (Fig. 3A \& B). Cryopreserved embryos were white to yellow when they were placed on recovery medium; viable embryos turned yellow to green after about 2 weeks; they converted to plants within an additional 2 week period and produced green shoots and roots (Fig. 3 C \& D). Callus formation was not observed in germinated embryos and no secondary embryos were produced after the droplet-vitrification procedure (Fig. 3 C). However, callus appeared together with germinated embryos after encapsulationvitrification (Fig. 3D).

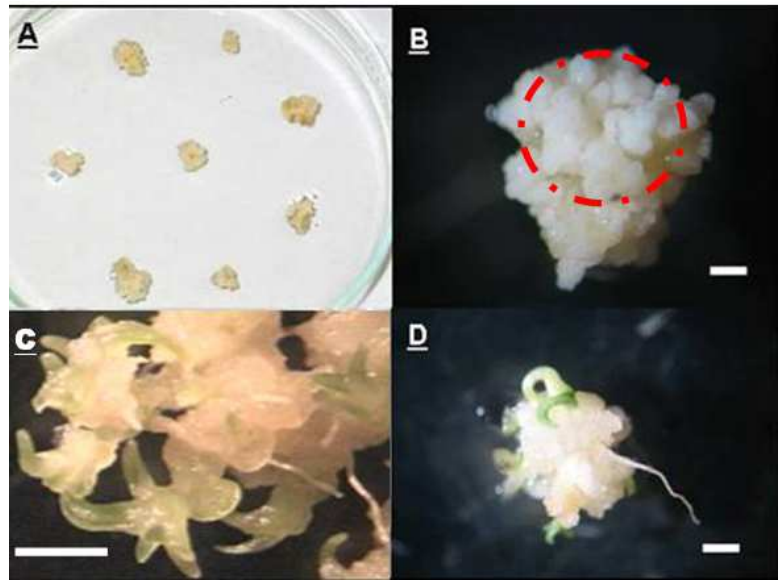

Fig. 3. Initial embryogenic sugarcane callus (A); clumps of somatic embryos selected for cryopreservation experiments (dashed line) (B); recovered clumps of somatic embryos after cryopreservation and 4 weeks after transfer to MS medium under light conditions ( $C$, using droplet-vitrification procedure; $\mathrm{D}$, using encapsulation-vitrification procedure) (bar $=1 \mathrm{~mm})$. 
The obtained results by Martinez-Montero et al., (2008) contrasted with what is generally observed in the literature, as vitrification is the most frequently employed vitrification-based procedure and it has been applied to a large number of species (Panis \& Lambardi, 2006; Sakai \& Engelmann, 2007). However, the number of successful reports of application of the droplet-freezing and encapsulation-vitrification techniques is increasing steadily (Engelmann, 2011).

Sugarcane somatic embryos proved very sensitive to PVS2, even though the PVS2 treatment was performed at $0^{\circ} \mathrm{C}$, which usually reduces the toxicity of the cryoprotectant solution (Benson, 2008). This high sensitivity rendered the utilization of the vitrification procedure impossible and alternative options had to be sought.

One of the options tested for cryopreservation of sugarcane somatic embryos was the encapsulation-vitrification technique, as developed by Matsumoto et al., (1995). These authors suggested that the toxicity of the PVS2 solution could be reduced by encapsulating the explants in alginate beads. Encapsulation also made the manipulation of the material easier. The positive effect of employing this technique was confirmed by the results, as some viability was achieved after cryopreserving sugarcane embryos using encapsulationvitrification.

We also tested the droplet-vitrification technique with sugarcane embryos (MartinezMontero et al., 2008). Droplet vitrification combines the procedure called droplet-freezing, which has been established with cassava (Kartha \& Engelmann, 1994) and applied notably to potato (Schäfer-Menuhr et al., 1997) and asparagus shoot tips (Mix-Wagner et al., 2000), in which explants are cooled in a droplet of cryoprotectant solution with the vitrification procedure (Sakai et al., 1990), since explants are cooled in a droplet of PVS2 solution. Droplet-vitrification is relatively easy to implement and generally ensures high recovery after cooling (Sakai \& Engelmann, 2007). One of the advantages of this technique is the high cooling and warming rates achieved, compared with others procedures (Benson, 2007; Panis et al., 2005). These high cooling/warming rates ensure complete vitrification during cooling and reduce the risks of devitrification during warming of samples, which is important to avoid the lethal effects of intracellular ice crystal formation (Benson, 2008).

Moreover, Volk \& Walters (2006) concluded that PVS2 imparts its effect in the previtrified solution, and at lower temperature the cryoprotectant restricts the mobility of water molecules, so that they are unable to nucleate and ice crystals are not allowed to growth. Benson (2008) empathized that cryoprotection using droplet-vitrification involves a somewhat different principle, due to the behavior of water molecules contained in microdroplets of vitrification solution. If the biophysical conditions are optimal the droplets can become vitrified on direct exposure to liquid nitrogen.

\section{Use of analytical techniques for sugarcane cryopreservation protocols}

In the past, cryopreservation protocols have generally been developed using an empirical approach. However, considerable advances have been made in recent years in the use of analytical tools to enhance our current knowledge of the damages induced in biological tissues by cryopreservation (Engelmann, 2011). Various biophysical, biochemical and histocytological techniques are available for this purpose (Harding, 1999). Such analytical tools 
allow the detection of those components of a cryopreservation method which cause the most damage. Usually, these studies are correlated with survival responses and viability testing. However, the application of analytical tools for plant cryopreservation studies is still very scarce and in some cases they are costly to implement and complex to evaluate (Verleysen et al., 2004). Apart mention need the excellent review by Benson (2008) in which it is exposed that contemporary cryopreservation research is now supported by advanced biomolecular or 'omics' technologies, creating a new knowledge base which will hopefully help to solve some of the more difficult cryobiological challenges. However, it will become increasingly so as stakeholders invest in areas commonly interested in low temperature research. Therefore, our research experience is only limited to use non costly and complex analytical techniques yet.

\subsection{Effect of cryopreservation on the structural and functional integrity of cell membranes of sugarcane embryogenic callus}

Cell membranes are one of the main targets of numerous stressing events, including cryopreservation (Benson, 2007; Fahy et al., 1984; Engelmann, 2011). Various markers, including electrolyte efflux, lipid peroxidation products and cell membrane protein content, reflect the structural and functional integrity status of cell membranes after exposure to such stressing events (Harding, 1999; Verleysen et al., 2004).

Measurement of electrolyte leakage has been used notably for studying the desiccation and cryopreservation sensitivity of various recalcitrant seed species (Sun, 1999). Lipid peroxidation profiles have been used as markers of cell membrane damage during freezing of rice cell suspensions and of the coenocytic alga Vaucheria sessilis (Benson et al., 1992; Fleck et al., 1999). Watanabe et al., (1999) have shown that the acquisition of tolerance to cryopreservation of rice cells was related to changes in protein metabolism. An increasing number of proteins and peptides that might contribute to freezing tolerance by reducing the effects of dehydration associated with freezing have been identified (Thomashow, 1999). In the same way, Thierry et al., (1999) have observed in carrot somatic embryos the overaccumulation of boiling-stable proteins, which seems to be related to an increase in tolerance to cryopreservation. Besides, some enzymes, which are induced by low temperature, such as fatty acid desaturase and sucrose phosphate synthase, also contribute to freezing tolerance (Guy, 1999).

Our research group studied the effect of cryopreservation on the structural and functional integrity of cell membranes of sugarcane embryogenic calluses by measuring electrolyte leakage, lipid peroxidation products and membrane proteins (Fig. 4). Firstly, we showed (Martinez-Montero et al., 2002a) that survival and plantlet production were lower with cryopreserved sugarcane embryogenic calluses in comparison with unfrozen control calluses. However, the differences observed between control and cryopreserved calluses in the parameters studied to evaluate membrane structural and functional integrity, including electrolyte leakage, total cell membrane protein content, malondialdehyde and other aldehyde content were only transitory. Indeed, they had all disappeared within 3-4 days after freezing.

Electrolyte leakage, measured to evaluate the overall effect of cryopreservation on the semipermeability of plasma membranes, revealed a partial loss of membrane semipermeability 
in callus cells. The transitory character of the electrolyte efflux observed indicates that no dramatic mechanical cell membrane injuries were caused by cryopreservation; rather only reversible lesions were induced by this treatment. As part of this dynamic process, the electrolytes released by damaged cells may have been taken up by living cells.
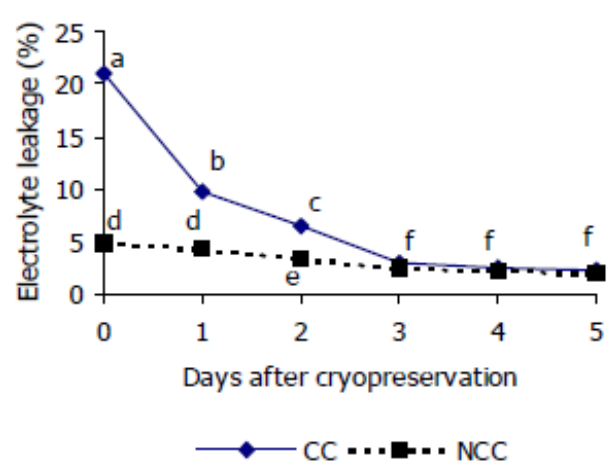

a
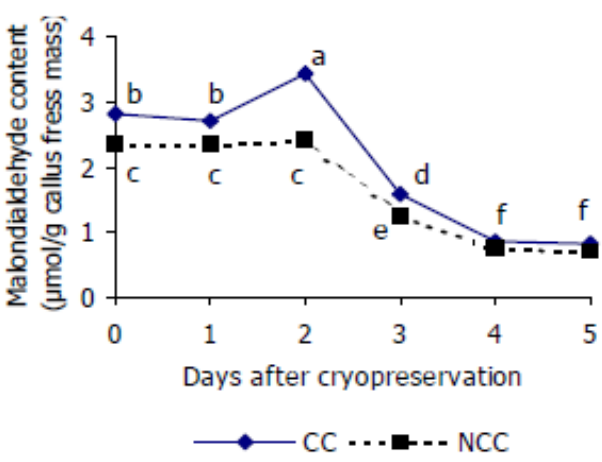

C
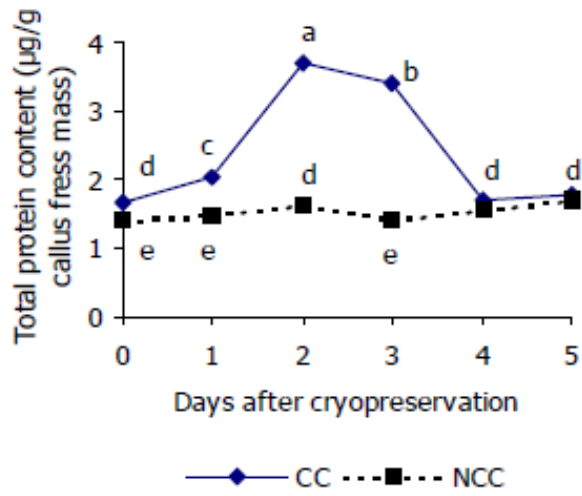

b
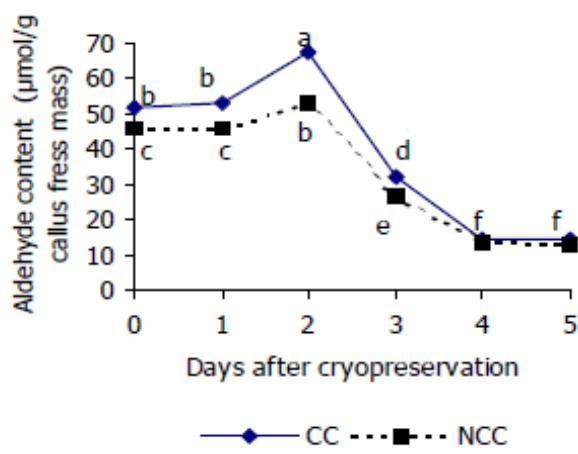

d

Fig. 4. Effect of cryopreservation on the structural and functional integrity of cell membranes of sugarcane embryogenic calluses by measuring electrolyte leakage (A), total proteins (B), malondialdehyde content (C) and other aldehyde content (D). Data followed by the same letter are not statistically different (ANOVA, Duncan, $p<0.05$ ). CC: cryopreserved callus. NCC: non-cryopreserved callus.

Freezing injury induces the production of free radicals, mainly reactive oxygen species (ROS) (Benson et al., 1992). The ROS signaling pathway is mainly controlled by the production of, and balance between, pro- and antioxidants and the perturbation of ROS homeostasis (Mittler et al., 2004). These changes are perceived by various proteins, enzymes and receptors which influence different developmental, metabolic and defense pathways. Free radicals then attack the lipid fraction of membranes, resulting in the formation of 
unstable lipid peroxides. These compounds breakdown to form toxic secondary oxidation products (Esterbauer et al., 1988) such as aldehydes, including malondialdehyde and other aldehydic products.

According to our results the main factors affecting sugarcane callus cell membrane damages and electrolyte efflux might thus be oxygen reactive species instead of malondialdehyde and aldehydes themselves, since the highest concentration of these compounds was reached later than the highest level of electrolyte leakage. However, it is also possible that the damages noted after cryopreservation could have been caused by the loss of cellular integrity due to the formation of ice crystals and to the cryoprotectants employed, which could damage the membranes.

We also showed that the content in malondialdehyde and other aldehydes in the microsomal fraction were higher for cryopreserved calluses than unfrozen controls, but only during the first three days after cryopreservation. Benson et al., (1992) have obtained similar results for malondialdehyde with cryopreserved rice cell suspensions. Therefore, they suggested that freezing stress could have caused disruption and uncoupling in some metabolic pathways as reported by Fleck et al. (1999) and Dumet et al., (2000) with other biological systems. This could have led to the production of free radicals, thus promoting lipid peroxidation in the cellular membranes of calluses at a very early post-thaw recovery stage.

Variations were also observed in control calluses, concerning mainly electrolyte leakage and lipid peroxidation. The significantly increased levels of malondialdehyde and aldehydes measured during the first 3 days in control calluses might be a result of mechanical membrane damage caused by cutting when preparing the starting material. Fleck et al., (1999) described an increase in lipid peroxidation products after cutting algae filaments into sections. In addition, transfer of material to fresh medium itself is another stress source that may cause an increase in malondialdehyde and aldehydes (Benson, 2007).

The concentration of lipid peroxidation products decreased from the second day onwards and reached a constant value on the fourth day in both frozen and control calluses (Martinez-Montero et al., 2002a). This decrease must have been caused by the activation of antioxidant defense mechanisms. Plants produce antioxidant molecules and have scavenging systems (ß-carotenes, tocopherol isomers, ascorbic acid, glutathione) and enzymatic free radical processing systems (superoxide dismutase, catalase, glutathione reductase, ascorbate peroxidase and various other enzymes) as a protective response to stresses (Leprince et al., 1993). Those antioxidant systems are directly activated by oxidative stress and, consequently, diminish the levels of ROS and thiobarbituric acid reactive substances in cells. Martinez-Montero et al., (2002a) suggested additional experiments to be performed to measure the concentration of such antioxidant molecules and the activity level of the above-cited enzymes in sugarcane embryogenic calluses in relation to cryopreservation.

An increase in cell membrane-related proteins has been described as a response to dehydration and freezing stress (Ausborn et al., 1994). Such proteins are produced as a protective mechanism to preserve membrane structure, ion sequestration and chaperon-like functions (Thierry et al., 1999). According to Martinez-Montero et al., (2002a) the total 
microsomal fraction protein content was higher in cryopreserved sugarcane calluses during the first $3 \mathrm{~d}$ after thawing. This increase was concomitant with an increase in malondialdehyde and aldehyde concentration. They hypothesized that some of the proteins induced by the freeze-thaw cycle may play a role in decreasing the malondialdehyde and aldehyde levels, in addition to the other functions mentioned above.

Even though electrolyte leakage, malondialdehyde, aldehyde and cell membrane protein contents became similar in control and cryopreserved samples $4 \mathrm{~d}$ after cryopreservation, cryopreservation consistently affected callus survival and plantlet regeneration (MartinezMontero et al., 2002a). However, lipid peroxidation products (such as malondialdehyde and aldehydes) might have impaired various cell functions in the sugarcane embryogenic calluses by cross-linking to macromolecules such as DNA and proteins to form mutagenic compounds as reported by Yang \& Scaich, (1996) for animal cells. Moreover, the free radicals induced by freezing stress are considered both cytotoxic and genotoxic because they are capable to modify protein structure, to form complexes with DNA and enzymes and to inhibit nucleic acid synthesis (Esterbauer et al., 1988; Grune et al., 1997, Spiteller, 1996). Such impairments might have affected the totipotency of these callus cells.

\subsection{Use of electrolyte leakage technique for sugarcane somatic embryos}

To allow a quick, reliable prognosis of the experiments performed and to refine the optimal conditions for cryopreservation of somatic embryos, viability was estimated using an electrolyte efflux test by our research group (Martinez-Montero et al., 2008). Firstly, four dissected clumps were either immediately incubated in $20 \mathrm{ml}$ double-distilled water or immersed directly in liquid nitrogen before incubation. The percentage of living cells (cell viability) was calculated by making mixtures of cooled and non cooled clumps (ca. $20 \mathrm{mg}$ total fresh weight). Conductivity of the water was measured before (C0) and after 5,15 or 25 $\mathrm{h}$ of imbibition $(\mathrm{Cx})$. Samples were then autoclaved $\left(30 \mathrm{~min}\right.$ at $\left.112^{\circ} \mathrm{C}, 107 \mathrm{kPa}\right)$ and cooled down to room temperature for $4 \mathrm{~h}$ to determine the total conductivity (Ctotal). The percentage of electrolyte leakage was calculated from the ratio: $(C x-C 0)^{*} 100 /($ Ctotal $-C 0)$. Lastly, a regression analysis was made between the results of the electrolyte leakage test and the cell viability (both were expressed in percentages). The best model that was suitable to represent the experimental data constitutes a standardized curve for analysis of cell viability during all experimentations.

The effect of the imbibitions duration in double-distilled water on the leakage of electrolytes in mixtures of cooled and non-cooled clumps by regression analysis demonstrated that there was a significant linear relationship $(\alpha=0.05)$ between the electrolyte efflux and the viability of somatic embryos and high coefficients of determination $\left(\mathrm{R}^{2}>0.88\right)$ were obtained (Fig. 5). It was clearly observed that a greater functional relationship existed in the lineal equation for imbibitions periods of clumps between 15 and $25 \mathrm{~h}$. Our results confirmed that an equilibration period was necessary for accurate measurement of cell leakage and the electrolyte leakage was practically complete $(85 \%$ of the electrolytes leaked in a sample with $100 \%$ of cooled clumps) after $15 \mathrm{~h}$ only. Moreover, the values of electrolyte leakage indicated that close to $10 \%$ of the somatic embryos were damaged after dissection for the cryopreservation experiments. Therefore, our test proved useful and precise as it was not only good for distinguishing between living and dead tissues but also for quantifying small differences in the amount of viable tissues. 


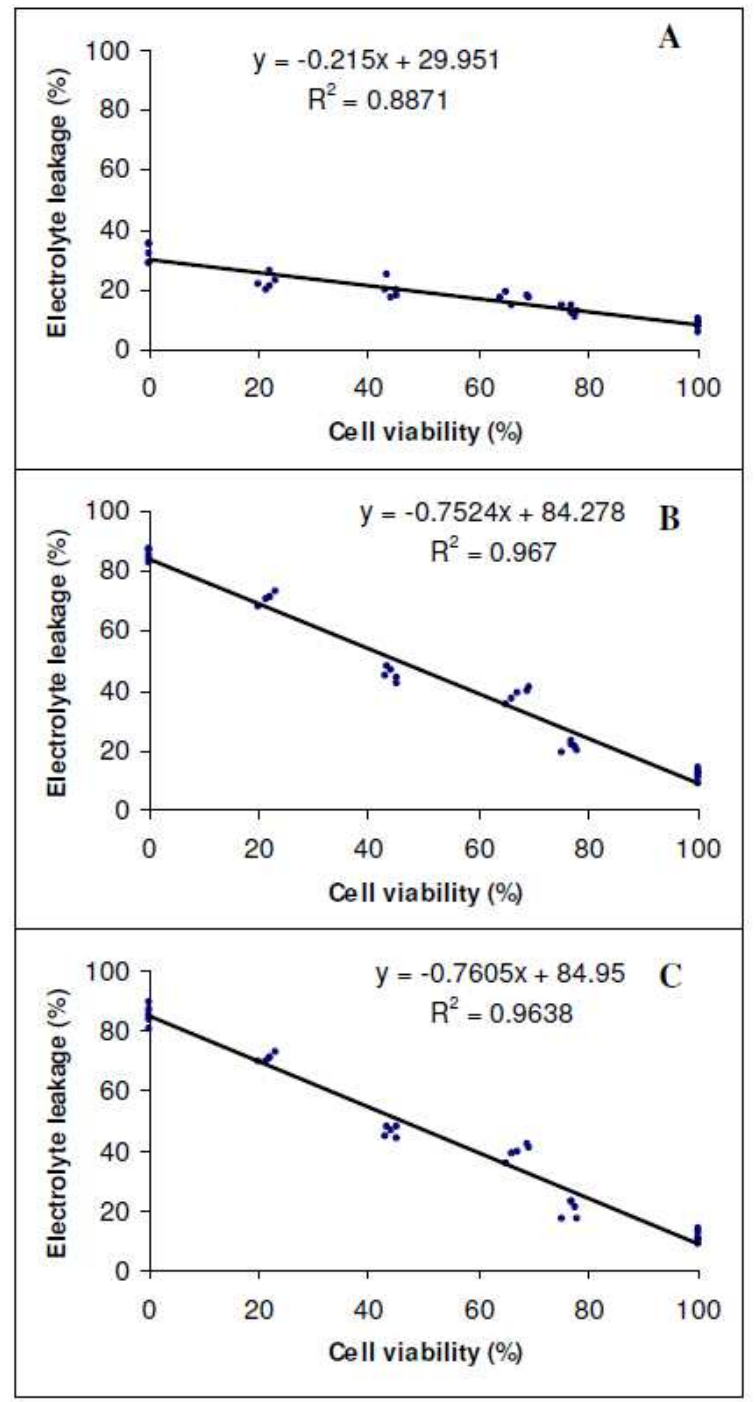

Fig. 5. Effect of the imbibition duration in double-distilled water on the leakage of electrolytes in mixtures of cooled and non-cooled clumps by regression analysis to determine the cell viability of sugarcane somatic embryos. A) after $5 \mathrm{~h}$; B) after $15 \mathrm{~h}$; C) after $25 \mathrm{~h}$.

\subsubsection{Optimization of methodology for somatic embryos}

The loading treatment is an essential step to achieve high post-rewarming survival of cryopreserved sugarcane somatic embryos because it induces or enhances tolerance of samples to PVS2 treatment (Panis \& Thinh, 2001). A loading solution including $2 \mathrm{M}$ glycerol 
and $0.4 \mathrm{M}$ sucrose is the most commonly employed in cryopreservation protocols (Sakai \& Engelmann, 2007). The results obtained by Martinez-Montero et al., (2008) showed that modifying the composition of the loading solution improved viability according to electrolyte efflux test for cryopreserved sugarcane embryos.

This indicates the importance of carefully studying each step of the cryopreservation protocol to optimize survival. We hypothesized that increasing the number of $\mathrm{OH}$ groups present in the loading medium progressively decreased viability of control sugarcane somatic embryos, whereas there was an optimum in their number to achieve highest viability after cryopreservation (Fig. 6). It has been suggested that $\mathrm{OH}$ groups of sugars/polyalcohols replace water and interact with phospholipids forming hydrogen bonding with membrane phospholipids (Turner et al., 2001). This helps stabilizing cellular membranes during dehydration and cooling and helps maintaining membrane integrity and function through minimizing bilayer disruption and damages (Benson, 2007).

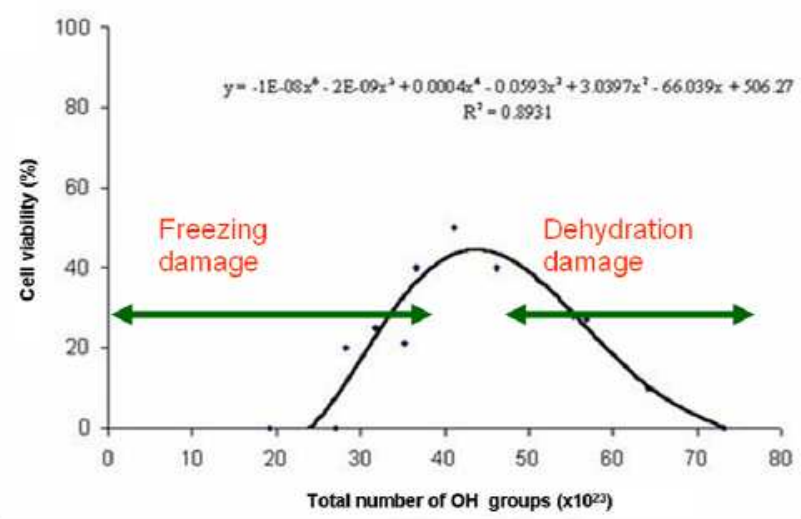

Fig. 6. Effect of the total number of $\mathrm{OH}$ groups of glycerol and sucrose on the cell viability of the cryopreserved sugarcane somatic embryos by droplet-vitrification procedure.

From a thermodynamic, kinetic, and structural point of view, the physico-chemical mechanism by which glycerol plus sucrose as co-solvent system can modulate the functionality of a given protein is very important (Baier \& McClements, 2005; Ruan et al., 2003). However, the stabilization mechanism of these agents has been attributed to a protein preferential hydration mechanism, as proposed by Timasheff (1993) or to an osmotic stress (Parsegian et al., 1995) where, mathematically, the two mechanisms cannot be distinguished (Parsegian et al., 2000).

In a very well documented paper, Parsegian et al., (2000) indicated that there has been much confusion about the relative merits of different approaches, osmotic stress, preferential interaction (i.e. preferential hydration), and crowding, to describe the indirect effect of solutes on macromolecular conformations and reactions. The two first mechanisms (and crowding) cannot be distinguished as they are derived from the same solution theory. In the preferential hydration model proposed by Timasheff (1993), both the chemical nature and the size of the solute determine water exclusion from the protein surfaces. The osmotic stress emphasizes the role of the water that is necessarily included if solutes are excluded 
(Parsegian et al., 2000), dealing also with the movement of water molecules (Parsegian et al., 1995; Stanley et al., 2008).

Duan et al., (2001) observed that the hydroxyl groups present in the glucose units could contribute to protein-sugar interactions in aqueous solutions. These newly formed dipoledipole interactions could form a hydrophilic layer around the protein units and therefore increase the dispersability of the protein through protein hydration and/or alter the intramolecular interactions in such a way that folding and even dissociation may be favoured (Semenova et al., 2002).

\section{Stability assessment}

Before using cryopreservation as an additional tool in the overall conservation strategy for any plant material, it is essential to verify that the cryopreservation protocol developed does not have any destabilizing effect and that the plants produced from cryopreserved explants are true to type (Harding, 2004). This author firstly provided a definition for "Cryobionomics" - a novel term describing the remodeled concept of genetic stability and the re-introduction of cryopreserved plants into the environment. Later, Cryobionomics is proposed as an approach to explore links between cryoinjury and genetic instability during and after cryopreservation (Harding et al., 2005, 2008b). There are an increasing number of reports indicating that no changes are observed in the material regenerated from cryopreservation (Engelmann, 1997). However, most of these experiments have been performed very soon after cryopreservation on a small number of individuals, often using material still cultured in vitro or after a very short period of growth in vivo and they concern mainly in vitro growth characteristics, or a limited number of biochemical or molecular markers. Only in a limited number of cases (e.g. Côte et al., 2000; Engelmann, 1997; SchäferMenuhr et al., 1997) have plants been grown in the field for a long period allowing the assessment of agronomic characteristics.

In the case of sugarcane, numerous experiments have been conducted to study the field behaviour of micropropagated plants (Feldmann et al., 1994; Flynn \& Anderlini, (1990); Jackson et al., 1990; Lorenzo et al., 2001; Pena \& Stay, 1997), uncovering the occurrence of rejuvenation phenomenons and of epigenetic changes. By contrast, only limited information is available concerning the stability of plants regenerated from cryopreserved material. RFLP analysis did not reveal any difference that could be attributed to cryopreservation between plants of one sugarcane variety produced from control and cryopreserved calluses (Eksomtramage et al., 1992) or cell suspensions (Chowdhury \& Vasil 1993). Plants produced from control and cryopreserved shoot tips of one variety were similar as regards pattern of two isoenzymatic systems (Paulet et al., 1993) and six agronomic traits observed during their early growth in vivo (Gonzalez-Arnao et al, 1999).

Moreover, we published data on the field performance of sugarcane plants originating from cryopreserved material (Martinez-Montero et al., 2002b). The field performance of plants produced from embryogenic calluses of one sugarcane commercial hybrid cv. CP52-43 (CP43-64 x CP38-34, Canal Point, USA) cryopreserved using the protocol developed by Martinez-Montero et al. (1998) was evaluated over a period of 27 months by observing several agronomic parameters (Fig. 7). Similar observations were carried out simultaneously for comparison on plants produced from the same callus cultures, but which were not cryopreserved and on plants of the same variety originating from classical macropropagation. 


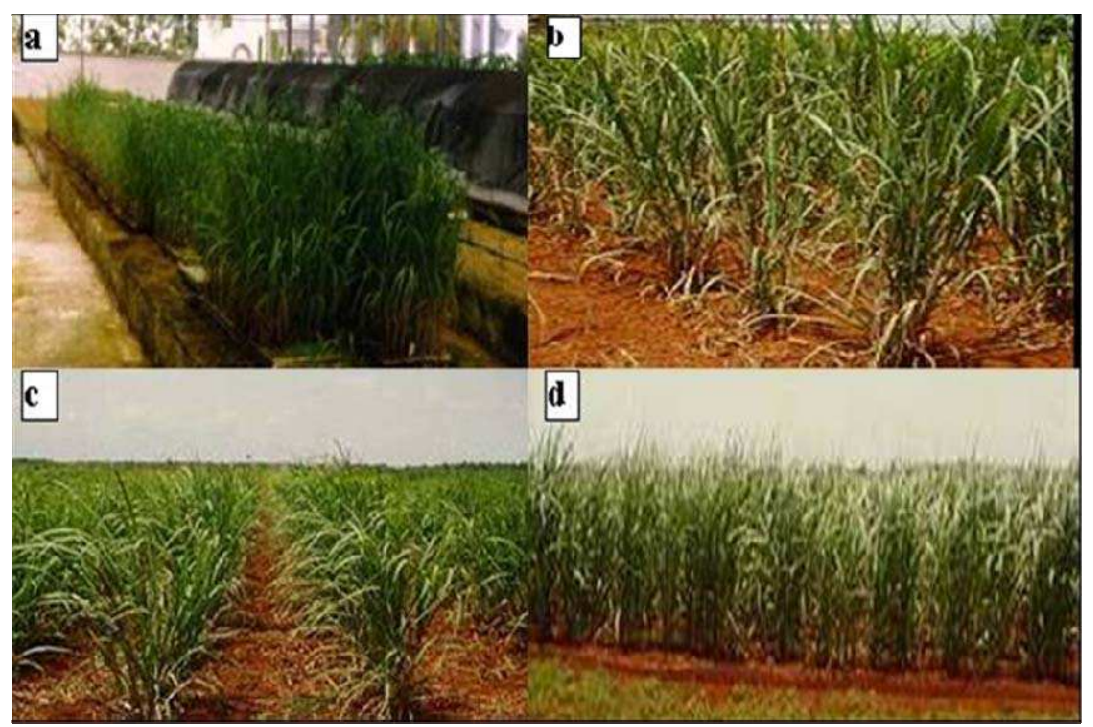

Fig. 7. Regenerated plants from cryopreserved embryogenic sugarcane callus a) during acclimatization (42 days); b, c) after 12 months in the field of the stool; d) after 15 months in the field of the first ratoon.

Treatments were distributed following a randomised block experimental design including four repetitions per treatment. Experimental plots were $7.5 \mathrm{~m}$ long with 5 rows each. Intrarow spacing was $0.5 \mathrm{~m}$. The commercial hybrid C266-70 (Co281 x POJ2878, INICA, Cuba) was planted as experiment border. Fertilization at the time of planting included $75 \mathrm{~kg} / \mathrm{ha}$ urea; $50 \mathrm{~kg} / \mathrm{ha} \mathrm{P}_{2} \mathrm{O}_{5}$ and $50 \mathrm{~kg} / \mathrm{ha} \mathrm{K}_{2} \mathrm{O}$. Additionally, $75 \mathrm{~kg} / \mathrm{ha}$ urea were supplied 3 months after planting. The following measurements were performed on 100 plants originating from cryopreserved calluses, control calluses and macropropagated plants:

- After 6 months of stool field growth: number of stems per clump (i.e. number of suckers produced from the original plant); stem diameter $(\mathrm{cm})$; stem length $(\mathrm{m})$.

- After 12 months of stool field growth: number of stems per clump; stem diameter $(\mathrm{cm})$; stem length $(\mathrm{m})$; fibre percentage $(\mathrm{w} / \mathrm{w})$; juice brix (i.e. mass of sugar (g dry matter) per $100 \mathrm{~g}$ of juice, expressed in Brix degree) ; pol (total sugar content) percentage in juice; pol percentage in cane; juice apparent purity tons of pol/ha.

- After cutting of stools and 15 months of field growth of the first ratoon: number of stems per clump; stem diameter $(\mathrm{cm})$; stem length $(\mathrm{m})$; single stem fresh mass $(\mathrm{kg})$; fibre percentage $(\mathrm{w} / \mathrm{w})$; juice brix; pol percentage in juice; pol percentage in cane; juice apparent purity; tons of $\mathrm{pol} / \mathrm{ha}$.

The results of the evaluation of field grown sugarcane plants after different periods showed significant differences between treatments only during the first six months of field growth of sugarcane stools (Table 4). Stems produced from in vitro cultured materials, irrespective of their cryopreservation status, had a smaller diameter and a shorter height than those produced from macropropagated buds. These differences disappeared during the course of the experiment as they were not observed anymore after 12 months of stool field growth. 


\begin{tabular}{|c|c|c|c|c|}
\hline \multirow[b]{2}{*}{ Parameter measured } & \multicolumn{3}{|c|}{ Origin of stools } & \multirow[b]{2}{*}{$\begin{array}{c}\text { Typical } \\
\text { Error }\end{array}$} \\
\hline & $\begin{array}{c}\text { Cryopreserved } \\
\text { calluses }\end{array}$ & Control calluses & Buds isolated & \\
\hline Stem diameter $(\mathrm{cm})$ & $1,51 \mathrm{~b}$ & $1,45 \mathrm{~b}$ & $1,82 \mathrm{a}$ & 0,12 \\
\hline Stem length $(\mathrm{m})$ & $0,57 \mathrm{~b}$ & $0,49 \mathrm{~b}$ & $0,85 \mathrm{a}$ & 0,10 \\
\hline Number of stems per meter & $5,20 \mathrm{a}$ & $5,45 \mathrm{a}$ & $4,22 \mathrm{~b}$ & 0,35 \\
\hline
\end{tabular}

Table 4. Evaluation of several agronomic parameters after six months of field growth of sugarcane stools originating from cryopreserved calluses, control (non-cryopreserved) calluses and buds isolated from macropropagated plants. Data in rows followed by the same letter are not statistically different (ANOVA, Tukey test, $p<0,05)$.

No significant difference between treatments was observed for any of the parameters studied after 12 months of stool field growth and 15 months of field growth of the first ratoon (Tables 5 and 6). This study has demonstrated that the differences observed for several agronomic characters between stools originating from cryopreserved and control calluses, and macropropagated material after 6 months of field growth disappeared progressively with time, as no differences could be uncovered in stools after 12 months nor after 15 months of field growth of the first ratoon.

Only very few published reports on this topic deal with comparable number and duration components. No differences have been noted in the vegetative and floral development of several hundreds of palms regenerated from control and cryopreserved oil palm embryogenic cultures, but no detailed account of the observations made has been published (Engelmann, 1997). The most comprehensive study is the comparison of the field behaviour of banana plants regenerated from control and cryopreserved cell suspensions (Côte et al., 2000), which showed that two out of the eleven descriptors analyzed differed between control and cryopreserved material during the first culture cycle but that, similarly to our observations, these differences disappeared during the second culture cycle.

\begin{tabular}{|c|c|c|c|c|}
\hline \multirow{2}{*}{ Parameter measured } & \multicolumn{3}{|c|}{ Origin of stools } & Typical \\
\cline { 2 - 4 } & $\begin{array}{c}\text { Cryopreserved } \\
\text { calluses }\end{array}$ & $\begin{array}{c}\text { Control } \\
\text { calluses }\end{array}$ & $\begin{array}{c}\text { Buds } \\
\text { isolated }\end{array}$ & Error \\
\hline Stem diameter $(\mathrm{cm})$ & 2,58 & 2,51 & 2,66 & 0,09 \\
\hline Stem length $(\mathrm{m})$ & 1,85 & 1,90 & 1,70 & 0,11 \\
\hline Stem fresh weight $(\mathrm{kg})$ & 1,37 & 1,33 & 1,49 & 0,09 \\
\hline Stem number per meter & 9,80 & 10,55 & 9,32 & 1,50 \\
\hline Agriculture recovery (t/ha) & 111,88 & 116,93 & 115,72 & 2,62 \\
\hline Juice brix $\left({ }^{\circ}\right.$ Brix) & 22,07 & 21,22 & 24,69 & 1,87 \\
\hline Pol percentage in juice $(\%, \mathrm{w} / \mathrm{w})$ & 19,17 & 18,37 & 19,35 & 1,93 \\
\hline Fibre percentage $(\%, \mathrm{w} / \mathrm{w})$ & 11,55 & 11,23 & 11,52 & 0,43 \\
\hline Pol percentage in cane $(\%, \mathrm{w} / \mathrm{w})$ & 16,95 & 16,30 & 17,12 & 1,90 \\
\hline Agro-industrial recovery $(\mathrm{t} / \mathrm{ha})$ & 18,96 & 19,06 & 19,81 & 1,51 \\
\hline
\end{tabular}

Table 5. Evaluation of several agronomic parameters after 12 months of field growth of sugarcane stools originating from cryopreserved calluses, control (non-cryopreserved) calluses and buds isolated from macropropagated plants. No statistical differences were found (ANOVA). 
An interesting result in our study is that plants regenerated from control and cryopreserved calluses displayed the same differences in comparison with those originating from macropropagated material. These differences are therefore not induced by cryopreservation but are due to the fact that both groups of plants originate from in vitro cultured material. It is indeed a well known phenomenon that tissue culture induces temporary changes in the behaviour of in vitro cultured plants during their early in vivo growth phase (Swartz 1991). Such changes can be induced by in vitro culture conditions including notably low light intensity, high humidity, limited gas exchanges, presence of high sucrose concentrations and growth regulators in the medium.

In the case of sugarcane, changes in the field behaviour of plants have been frequently observed after in vitro culture. Several authors have reported an increase in the number of new stems per clump (Flynn \& Anderlini, 1990; Jackson, 1990; Perez et al., 1999), which generally induces a reduction in the stem diameter and mass. Peña \& Stay (1997) stated that, with sugarcane in vitro culture stimulated growth and vigour, induced rejuvenation and generally improved agricultural performance. Many authors (Jimenez et al., 1991; Lorenzo et al., 2001; Lourens. \& Martin 1987; Taylor et al., 1992) indicate that such differences disappear during the course of field growth and the first clonal multiplication, as observed in our experiments.

\begin{tabular}{|c|c|c|c|c|}
\hline \multirow{2}{*}{ Parameter measured } & \multicolumn{3}{|c|}{ Origin of stools } & Typical \\
\cline { 2 - 4 } & $\begin{array}{c}\text { Cryopreserved } \\
\text { calluses }\end{array}$ & $\begin{array}{c}\text { Control } \\
\text { calluses }\end{array}$ & $\begin{array}{c}\text { Buds } \\
\text { isolated }\end{array}$ & Error \\
\hline Stem diameter (cm) & 2,62 & 2,59 & 2,65 & 0,10 \\
\hline Stem length (m) & 1,93 & 1,98 & 2,04 & 0,16 \\
\hline Stem fresh weight (kg) & 1,50 & 1,51 & 1,54 & 0,21 \\
\hline Stem number per meter & 9,77 & 9,65 & 10,09 & 2,20 \\
\hline Agriculture recovery (t/ha) & 122,10 & 121,42 & 129,48 & 5,12 \\
\hline Juice brix ( ${ }^{\circ}$ Brix) & 23,22 & 23,02 & 22,98 & 1,79 \\
\hline $\begin{array}{c}\text { Pol percentage in juice (\%, } \\
\text { w/w) }\end{array}$ & 20,45 & 20,07 & 19,95 & 1,85 \\
\hline Fibre percentage (\%, w/w) & 12,9 & 12,17 & 12,5 & 0,35 \\
\hline $\begin{array}{c}\text { Pol percentage in cane (\%, } \\
\text { w/w) }\end{array}$ & 17,81 & 17,62 & 17,45 & 1,80 \\
\hline $\begin{array}{c}\text { Agro-industrial recovery } \\
\text { (t/ha) }\end{array}$ & 21,75 & 21,35 & 22,59 & 1,51 \\
\hline
\end{tabular}

Table 6. Evaluation of several agronomic parameters after 15 months of field growth of the first sugarcane ratoon originating from cryopreserved calluses, control (non-cryopreserved) calluses and buds isolated from macropropagated plants. No statistical differences were found (ANOVA).

In conclusion, the results obtained in our study validate the cryopreservation protocol developed by Martinez-Montero et al. (1998) for embryogenic calluses. Cryopreservation of embryogenic calluses will thus be incorporated in the scheme established by the Centro de 
Bioplantas for mass production of in vitro sugarcane plants by means of somatic embryogenesis.

\section{Cryopreservation protocols for pineapple}

Pineapple is vegetatively propagated and crosses between varieties produce botanical seeds. However, these seeds are highly heterozygous and therefore of limited interest for the conservation of specific gene combinations. Cryopreservation of apices is the most relevant strategy for long-term conservation of vegetatively propagated crops, since true to type; virus free plants can be regenerated directly from cryopreserved apices (Lynch et al., 2007).

Vitrification and encapsulation-dehydration techniques have been widely applied for successfully cryopreserve apices of a large number of different crops which do not require sophisticated equipment for freezing and produce high recovery rates with a wide range of materials (Engelmann, 2010, 2011). Most vitrification protocols use a loading treatment and a stringently timed dehydration with PVS (Benson, 2008b). This two-step procedure has allowed tissues to be more tolerant to osmotic stress and to resist the chemical toxicity induced by the highly concentrated cryoprotective solutions. Exposure duration to PVS is usually not longer than $2 \mathrm{~h}$ (Thinh et al., 1999).

The encapsulation-dehydration method for cryopreservation is based on the fact that encapsulation protects the explants and preculture in medium enriched with osmoticum makes them tolerant to air drying (Fabre \& Dereuddre, 1990). Preculture in $0.75 \mathrm{M}$ sucrose and desiccation to about $25 \%$ water content in beads (fresh weight basis) are the most common conditions used (Gonzalez-Arnao et al., 1996). The application of vitrification solutions to dehydrate encapsulated cells or shoot tips has also been successfully applied to several species (Engelmann, 2004).

\subsection{Apices}

The first successful result related with the cryopreservation of pineapple (Ananas comosus) apices was reported by our group in Cuba (Gonzalez-Arnao et al., 1998b). The encapsulation and vitrification techniques were experimented for freezing apices of pineapple in vitro plantlets. Positive results were achieved using vitrification only (Fig. 8). Optimal conditions included a 2 day preculture of apices on medium supplemented with $0.3 \mathrm{M}$ sucrose, loading treatment for $25 \mathrm{~min}$ in medium with $0.75 \mathrm{M}$ sucrose $+1 \mathrm{M}$ glycerol and dehydration with PVS2 vitrification solution at $0^{\circ} \mathrm{C}$ for $7 \mathrm{~h}$ before rapid immersion in liquid nitrogen. This method resulted in ranged survival $(25-65 \%)$ depending of the genotypes. Recovery of cryopreserved apices took place directly, without transitory callus formation.

The negative results after cryopreservation of pineapple apices by encapsulationdehydration technique can be related to the high sensitivity of pineapple apices to sucrose and dehydration. Pregrowth in media with sucrose concentrations higher than $0.5 \mathrm{M}$ was detrimental to survival and a prolonged treatment in $0.5 \mathrm{M}$ sucrose was required to improve survival after desiccation, but it was not sufficiently to obtain survival of apices after freezing. The viability loss observed after freezing may be due to the crystallization of 
remaining freezable water upon freezing. This detrimental crystallization might be avoided by slowly freezing of the encapsulated apices, which would result in removing the remaining freezable water by means of freeze-induced dehydration. Several plant materials cryopreserved by encapsulation-dehydration technique have required slow freezing regime to achieved optimal survival (Engelmann, 2010).

In another set of experiments, our group obtained positive results again only with vitrification (Martinez-Montero et al., 2005). The best protocol comprised a 2-d preculture on semi-solid MS medium supplemented with $0.3 \mathrm{M}$ sucrose, a loading treatment in liquid medium containing $0.4 \mathrm{M}$ sucrose $+2 \mathrm{M}$ glycerol for $25 \mathrm{~min}$, and dehydration for $7 \mathrm{~h}$ at $0^{\circ} \mathrm{C}$ with PVS3 before immersion into liquid nitrogen. The highest survivals of apices were: Smooth Cayenne (45\%), Cabezona (33\%) and Red Spanish (25\%).
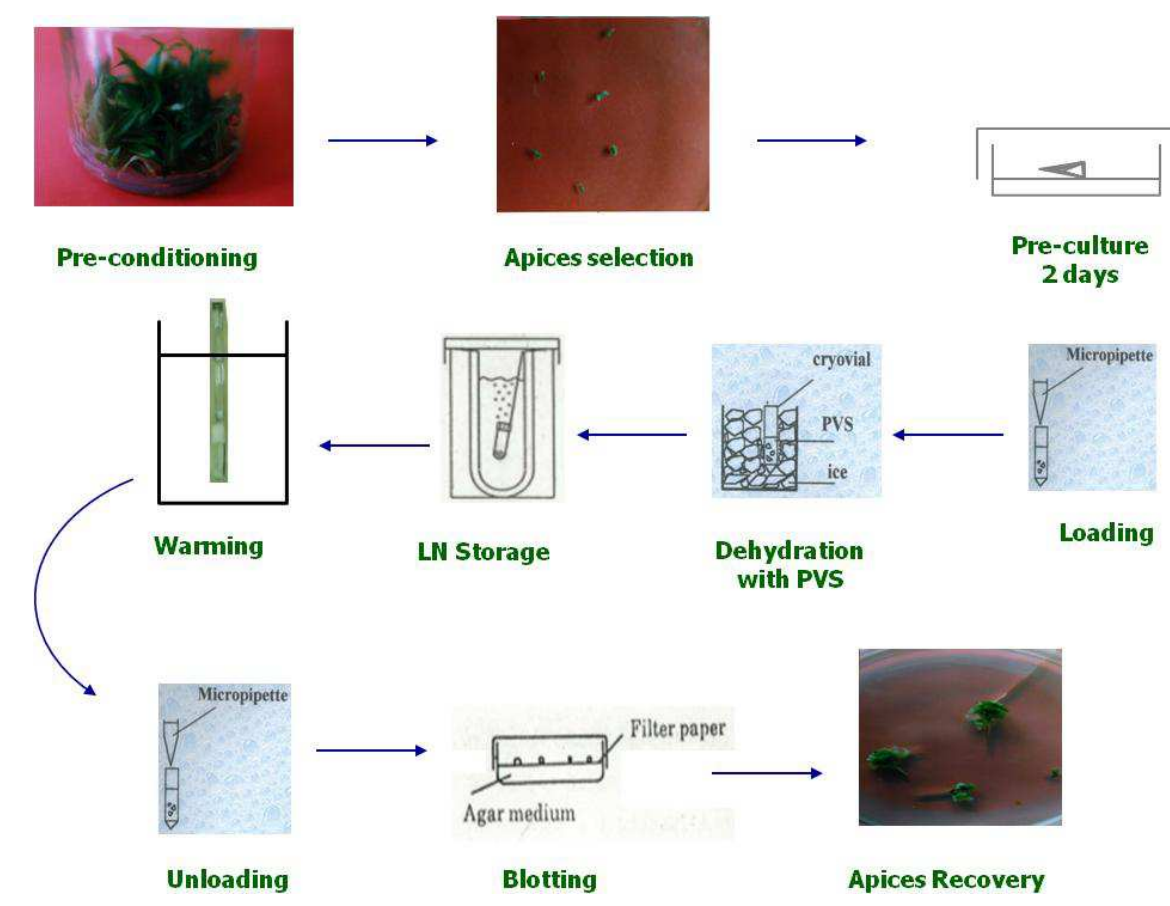

Fig. 8. Cryopreservation protocol established for pineapple apices using vitrification technique.

However, contrary to most vitrification reports, pineapple apices required a prolonged exposure $(7 \mathrm{~h})$ to the vitrification solutions (Engelmann, 2010). This result is probably due to the large size, and compact structure of the pineapple apices employed in our experiments with success (Fig. 9): the apices were around $3 \mathrm{~mm}$ long, and comprised the apical dome tightly covered by 2-3 leaf primordial with a very thick cuticle. Long treatment durations were needed for the vitrification solution to sufficiently dehydrate these very compact structures. 

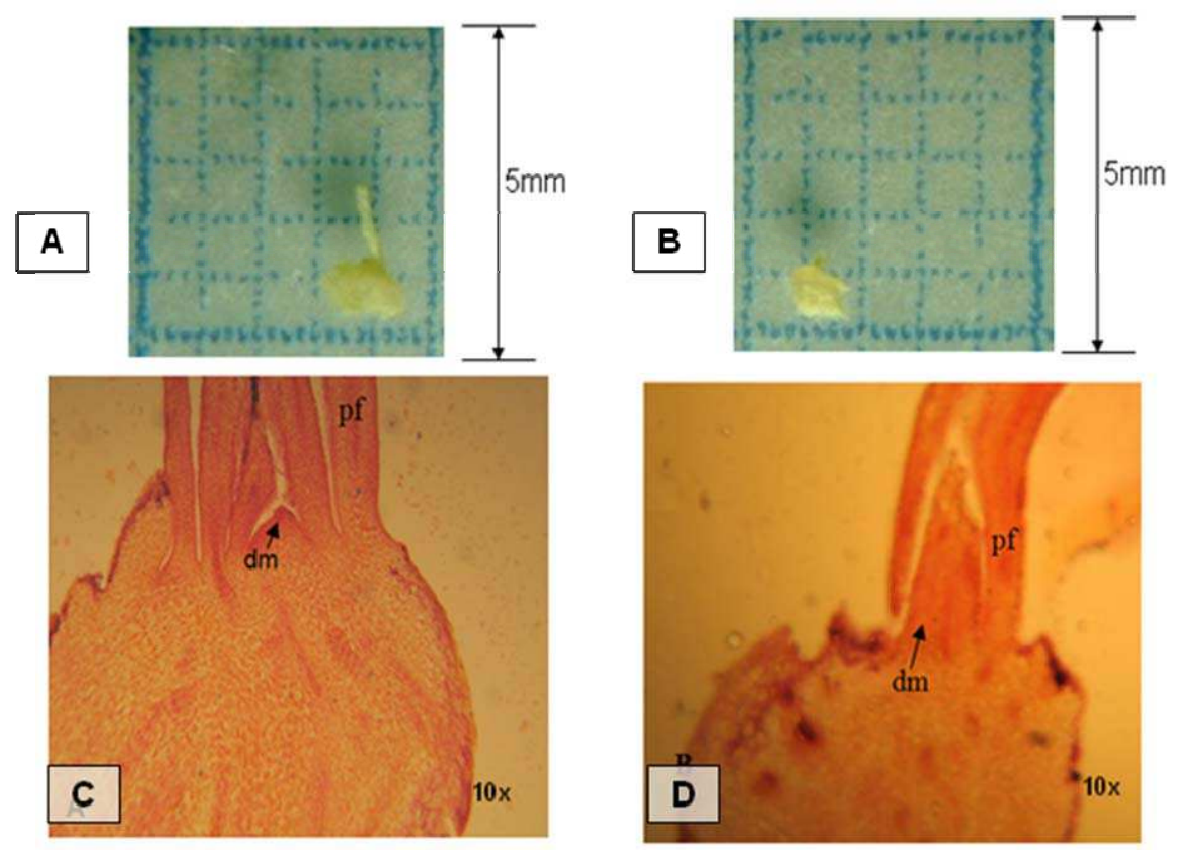

Fig. 9. Dissected pineapple (Ananas comosus L. Merrill cv. MD2) shoot tips as viewed by stereo-microscope (A, B); and by light microscopy 10x (C, D). Dissected apices type I (A, C) with apical dome (dm) and 3-4 primordial leaves (pf) and mechanical damaged apices type II $(\mathrm{B}, \mathrm{D})$ with one primordial leaf used as controls.

\subsubsection{Extension of vitrification protocol}

In the case of pineapple, it is believe as symbol in the province of Ciego de Avila (Cuba) due to great cultivated areas dedicated to this crop. In our Institution (Bioplantas Centre) is located the unique field collection of pineapple germplasm in the country. However, this field genebank is prone to disease, or damage through natural disaster and need very high maintenance. For this reason, the cryopreservation of apices obtained from vitroplants could constitutes the most relevant strategy for long-term conservation of pineapple germplasm, since true to type and virus-free plants can be regenerated directly from cryopreserved apices (Martinez-Montero et al., 2005).

The successful application of the vitrification protocol for nine accessions of the in vitro collection at Bioplantas Centre was accomplished with the following conditions: type of shoot tip (consisted in meristematic dome area and 3-4 primordial leaves with 2,5-3 mm in size); 0,3 mol.L-1 sucrose preculture during 2 days; application of the loading solution $(0,4$ mol.L-1 sucrose +2 mol. $\mathrm{L}^{-1}$ glycerol) during $25 \mathrm{~min}$ at $25^{\circ} \mathrm{C}$; dehydration with plant vitrification solution number three (PVS3: $50 \% \mathrm{w} / \mathrm{v}$ glycerol $+50 \% \mathrm{w} / \mathrm{v}$ sucrose) during 7 hours at $0^{\circ} \mathrm{C}$. The results per accessions expressed as percentage of recovery before (-LN) and after $(+\mathrm{LN})$ cryopreservation for six apices per replicate, four replicates per treatment and each experiment was repeated three times are showed in Table 7. 


\begin{tabular}{|c|c|c|}
\hline \multirow{2}{*}{} & \multicolumn{2}{|c|}{ Survival (\%) } \\
\cline { 2 - 3 } & -LN & +LN \\
\hline Cayenne of Puerto Rico & 80.2 & 65.5 \\
\hline Perolera & 49.9 & 33.8 \\
\hline Smooth Cayenne of Serrana & 50.3 & 25.3 \\
\hline Cabezona & 61.5 & 27.9 \\
\hline Piña Blanca of Caney & 57.9 & 24.7 \\
\hline P3R5 & 53.1 & 20.0 \\
\hline Red Spanish of Caney & 45.5 & 12.1 \\
\hline MD2 & 80.1 & 60.2 \\
\hline Bromelia sp. & 33.1 & 6.3 \\
\hline
\end{tabular}

Table 7. Effect of vitrification protocol on survival of apices from eight pineapple accessions and one related specie (Bromelia sp.) before (-LN) and after cryopreservation (+LN).

\subsubsection{Optimization of methodology for pineapple apices}

Further modifications to the procedures might be useful in order to reduce the exposure duration to PVS and achieve higher survival after cooling. Therefore, the objective was to develop a more effective cryopreservation protocol using both vitrification and encapsulation/vitrification. As previously we reported (Gonzalez-Arnao et al., 1998b; Martinez-Montero et al., 2005), pineapple apices are sensitive to sucrose and dehydration exposures. A progressive treatment increasing sucrose concentrations was effective at enhancing their tolerance to dehydration and cooling.

Proline has been shown to have a beneficial effect in several cryopreservation protocols (Luo \& Reed, 1997; Rasmunsen et al., 1997; Rudolf \& Crowe, 1985; Thierry et al., 1999). In our experiments we confirmed that a $2-d$ progressive preculture in a mixture of sucrose and proline improved the results obtained after cooling in comparison with sucrose alone. This modification in pregrowth also considerably reduced the required dehydration time in PVS. As previously reported, apices of Puerto Rico variety treated for $2 \mathrm{~d}$ in $0.3 \mathrm{M}$ sucrose needed an extended exposure $(7 \mathrm{~h})$ to PVS2 at $0^{\circ} \mathrm{C}$ to achieve high levels of survival $(65 \%)$ after cryopreservation. However, following the same vitrification approach, higher survival $(72 \%)$ was obtained using the best pretreatment in sucrose-proline and only $30 \mathrm{~min}$ of exposure to PVS2. As regards PVS3, we also demonstrated that $30 \mathrm{~min}$ or $1 \mathrm{~h}$ of dehydration were also enough to obtain higher survival (76 \%) after cryopreservation.

The role of proline has been associated with its ability to act as source of nitrogen and carbon for reparative post-stress processes (Rabbe \& Lova, 1984), to increase the nonfreezable fraction of water (Rasmussen et al, 1997), to inhibit membrane mixing and to stabilize proteins during dehydration and freezing (Rudolf \& Crowe, 1985). On the other hand, the combination of chemical cryoprotectants may also improve the response of tissues to cryopreservation in comparison with the application of one chemical alone. As reported for wasabi apices, a mixture of glycerol with sucrose was more effective at enhancing their 
tolerance to dehydration and deep cooling than a preculture in sucrose alone (Sakai et al, 2000).

Dehydration at $0^{\circ} \mathrm{C}$ instead of $25^{\circ} \mathrm{C}$ for both vitrification solutions gave better results, as previously reported for pineapple apices by our group. This low temperature reduces the toxicity of the vitrification solutions and increases the potential period of exposure (Withers \& Engelmann, 1997). In all our cryopreservation experiments, dehydration with PVS3 at $0^{\circ} \mathrm{C}$ gave higher recovery rates compared with PVS2, even for diverse genotypes. The encapsulation-vitrification method using PVS3 gave greater survival than the vitrification procedure. Additionally, the manipulation of encapsulated apices permits handling large quantities of material that from the practical point of view is more convenient. These results corroborated that encapsulation-vitrification may also be very useful for cryopreserving desiccation-sensitive germplasm such as pineapple, that could not be successfully cryopreserved using an encapsulation-dehydration approach (Gonzalez-Arnao et al., 2003).

The cryopreservation protocol presented here improved survival and shortened the process compared with previous protocols from our group (table 8). The optimal conditions involved the encapsulation of pineapple apices in calcium alginate $(3 \%)$ beads, followed by a 2-d progressive preculture in liquid medium with $0.16 \mathrm{M}$ sucrose $+0.3 \mathrm{M}$ proline for $24 \mathrm{~h}$, then $0.3 \mathrm{M}$ sucrose $+0.3 \mathrm{M}$ proline for $24 \mathrm{~h}$, a loading treatment for $25 \mathrm{~min}$ in $0.75 \mathrm{M}$ sucrose $+1 \mathrm{M}$ glycerol solution at room temperature and dehydration for $60 \mathrm{~min}$ with PVS3 at $0^{\circ} \mathrm{C}$ before rapid immersion into liquid nitrogen.

\section{Regrowth (\%)}

\begin{tabular}{|c|c|c|c|c|c|}
\hline \multirow[t]{2}{*}{ Variety } & \multirow{2}{*}{$\begin{array}{c}\text { Vitrification } \\
\text { Solution }\end{array}$} & \multicolumn{2}{|c|}{ Encapsulation-Vitrification } & \multicolumn{2}{|c|}{ Vitrification } \\
\hline & & $-L N$ & $+L N$ & $-\mathrm{LN}$ & $+\mathrm{LN}$ \\
\hline MD-2 & PVS2 & $75 \pm 2.7^{\text {a }}$ & $39 \pm 1.9^{d}$ & $68 \pm 1.0^{\circ}$ & $46 \pm 20^{\circ}$ \\
\hline & PVS3 & $76 \pm 1.9^{3}$ & $54 \pm 2.8^{\circ}$ & $72 \pm 2.0^{b}$ & $48 \pm 1.1^{\text {d }}$ \\
\hline $\begin{array}{l}\text { Puerto } \\
\text { Rico }\end{array}$ & PVS2 & $91 \pm 1.3^{\mathrm{a}}$ & $83 \pm 1.8^{\circ}$ & $88 \pm 1.5^{b}$ & $72+2.0^{d}$ \\
\hline & PVS3 & $93 \pm 2.2^{a}$ & $83 \pm 1.1^{b}$ & $88 \pm 1.4^{\circ}$ & $76 \pm 0.7^{\circ}$ \\
\hline
\end{tabular}

Different letters within rows imply significant differences according to Tukey test $(P<0.05)$ and each PVS.

Table 8. Comparison of the encapsulation-vitrification and vitrification procedures on regrowth (\%) of pineapple apices after dehydration with PVS2 or PVS3 solutions at $0^{\circ} \mathrm{C}$.

\subsection{Embryogenic callus}

The results of some studies indicated Fusarium subglutinans isolates cause fusariose which constitutes the most serious pineapple disease and causes losses as high as $80 \%$ of marketable pineapple fruit. It produces phytotoxins in culture that were phytotoxic on 
calluses (Jin et al., 1996; Kaur et al., 1987) and the correlation between pineapple variety and the toxicity of culture filtrates suggests that filtrates could be used to screen in vitro for disease resistance (Borras et al., 2001). Therefore, the cryopreservation of pineapple calluses can provide a means of effective source when in vitro screening of germplasm for fusariose disease would be attempted. Storing calluses in liquid nitrogen could preserve their regeneration capacity and limits the risk of somaclonal variation, which increases with culture duration.

A simplified freezing protocol mentioned before for sugarcane embryogenic calluses (Martinez-Montero et al., 1998) was used for pineapple calluses of the genotypes "Smooth Cayenne" and "Perolera" (Martinez-Montero et al., 2005). For cryopreservation experiments, 15 to 20 day-old calluses, about 3 to $6 \mathrm{~mm}$ in diameter, were employed. Calluses were pretreated with a cryoprotective solution containing 5 to $20 \%(\mathrm{v} / \mathrm{v})$ dimethylsulfoxide (DMSO) and $0.5 \mathrm{M}$ sucrose for $1 \mathrm{~h}$ at $0^{\circ} \mathrm{C}$. After freezing calluses were transferred directly to recovery medium (MS medium supplemented with dicamba:BAP (2.5:0.5 mg. $\left.\mathrm{L}^{-1}\right)$ and citric acid $\left.\left(0.1 \mathrm{mg} . \mathrm{L}^{-1}\right)\right)$. The survival, evaluated 45 days after thawing, corresponded to the percentage of calluses which had increased in size during the recovery period.

As results, the survival of calluses after pretreatment was high and similar for the two genotypes studied (Table 8). It decreased only with $20 \%$ of DMSO. After freezing in liquid nitrogen, survival was achieved with 10 and 15\% DMSO only and was highest with 15\% DMSO (57-67\%). Re-growth of successfully cryopreserved calluses was very rapid and they increased in size during the recovery period. With this work, the application of a simplified freezing protocol achieved survival from used pineapple genotypes and this confirm that our previously simplified freezing protocol for sugarcane (Martinez-Montero et al., 1998) can be used wider to others species.

\begin{tabular}{|c|c|c|c|c|c|}
\hline & \multicolumn{4}{|c|}{ Survival (\%) } \\
\hline & & \multicolumn{2}{|c|}{ Smooth Cayenne } & \multicolumn{2}{|c|}{ Red Spanish } \\
\hline $\begin{array}{c}\text { DMSO } \\
(\%)\end{array}$ & Sucrose (M) & $-\mathrm{LN}$ & $+\mathrm{LN}$ & $-\mathrm{LN}$ & $+\mathrm{LN}$ \\
\hline 5 & \multirow{4}{*}{0.5} & $85 \pm 11$ a & $0 \mathrm{c}$ & $87 \pm 6$ a & $0 \mathrm{c}$ \\
\hline 10 & & $81 \pm 8 \mathrm{a}$ & $25 \pm 3 b$ & $85 \pm 6 \mathrm{a}$ & $30 \pm 4 b$ \\
\hline 15 & & $75 \pm 12 \mathrm{a}$ & $57 \pm 7 \mathrm{a}$ & $80 \pm 6 a$ & $65 \pm 6 a$ \\
\hline 20 & & $55 \pm 6 b$ & $0 \mathrm{c}$ & $60 \pm 4 b$ & $0 c$ \\
\hline
\end{tabular}

Table 9. Effect of cryoprotective solution (DMSO + sucrose) on the survival rate (\%) before ($\mathrm{LN})$ and after (+LN) application of cryopreservation protocol for calluses of two pineapple genotypes. Values represent means of 50 samples from three replicate experiments, $\pm S E$. Means within columns followed by the same letter are not significantly different (ANOVA $p<0,05$ Tukey,). Data were transformed for statistical analysis in accordance with $x^{\prime}=2$ arcsine $\left((x / 100)^{0,5}\right)$ for percentage of survival.

\section{Conclusions}

For vegetatively propagated species, cryopreservation has a wide applicability both in terms of species coverage, since protocols have been successfully established for root and tubers, fruit trees, ornamentals and plantation crops, both from temperate and tropical origin and in 
terms of numbers of genotypes/varieties within a given species. With a few exceptions, vitrification-based protocols have been employed. It is also interesting to note that in many cases, different protocols can be employed for a given species and produce comparable results. Survival is generally high to very high. Regeneration is rapid and direct, and callusing is observed only in cases where the technique is not optimized. Different reasons can be mentioned to explain these positive results. The meristematic zone of apices, from which organised growth originates, is composed of a relatively homogenous population of small, actively dividing cells, with little vacuoles and a high nucleocytoplasmic ratio. These characteristics make them more susceptible to withstand desiccation than highly vacuolated and differentiated cells. As mentioned earlier, no ice formation takes place in vitrificationbased procedures, thus avoiding the extensive damage caused by ice crystals which are formed during classical procedures. The whole meristem is generally preserved when vitrification-based techniques are employed, thus allowing direct, organised regrowth. By contrast, classical procedures often lead to destruction of large zones of the meristems, and callusing only or transitory callusing is often observed before organised regrowth starts. Other reasons for the good results obtained are linked with tissue culture protocols. Many vegetatively propagated species successfully cryopreserved until now are cultivated crops, often of great commercial importance, for which cultural practices, including in vitro micropropagation, are well established. In addition, in vitro material is "synchronized" by the tissue culture, and pregrowth procedures and relatively homogenous samples in terms of size, cellular composition, physiological state and growth response are employed for freezing, thus increasing the chances of positive and uniform response to treatments. Finally, vitrification-based procedures allow using samples of relatively large size (shoot tips of 0.5 to $2-3 \mathrm{~mm}$ ), which can regrow directly without any difficulty. Cryopreservation techniques are now operational for large-scale experimentation in an increasing number of cases. In view of the wide range of efficient and operationally simple techniques available, any vegetatively propagated species should be amenable to cryopreservation, provided that the tissue culture protocol is sufficiently operational for this species.

\section{Acknowledgment}

The authors thank the Food and Agriculture Organization of the United Nations (FAO), the International Plant Genetic Resources Institute (IPGRI, actually Bioversity International) and the International Foundation for Science (IFS) for partly funding the research programme.

\section{References}

Anchordoguy, T.J.; Cecchini, C.A.; Crowe, J.H.; Crowe, L.M. (1991) Insights into the cryoprotective mechanism of dimethyl sulphoxide for phospholipid bilayers. Cryobiology 28(5), (October 1991), 467-473. ISSN: 0011-2240

Arakawa, T.; Carpenter, J.F.; Kita, Y.A.; Crowe, J.H. (1990) The basis for toxicity of certain cryoprotectants: An hypothesis. Cryobiology 27(4), (August 1990), 401-15. ISSN: 0011-2240

Aronen, T.S.; Krajnakova, J.; Haggman, H.M., Ryynannen, L.A. (1999) Genetic stability of cryopreserved embryogenic clones of white spruce (Picea glauca). Plant Cell Rep. 18, 948-953. ISSN: 0721-7714 
Ashmore, S.E. (1997) Status reports on the development and application of in vitro techniques for the conservation and use of plant genetic resources. International Plant Genetic Resources Institute, ISBN 92-9043-339-6, Rome, Italy.

Ausborn, M.; Schreier, H.; Brezesinski, G.; Fabian, H.; Meyer, H.W.; Nuhn, P. (1994) The protective effect of free and membrane bound cryoprotectants during freezing and freeze-drying of liposomes. J Control Release 30, 105-116. ISSN: 0168-3659

Baier, S.K. \& McClements, D.J. (2005) Influence of cosolvent systems on the gelation mechanism of globular protein: Thermodynamic, kinetic, and structural aspects of globular protein gelation. Comprehensive Reviews in Food Science and Food Safety 4, 43-54. ISSN: 1541-4337

Barraco, G.; Sylvestre, I.; Engelmann, F. (2011) Comparing encapsulation-dehydration and droplet-vitrification for cryopreservation of sugarcane (Saccharum spp.) shoot tips. Scientia Horticulturae, 130(1), (August 2011), 320-324. ISSN: 0304-4238

Benson, E.E. (2008a) Cryopreservation of phytodiversity: A critical appraisal of theory and practice. Critical Reviews in Plant Sciences 27(3), 141-219. ISSN: 0735-2689

Benson, E.E. (2008b) Cryopreservation theory. In: Plant Cryopreservation: A Practical Guide. Reed, B.M. Ed., pp. 15-32. Chapt. 2. Springer, ISBN 978-0-387-72275-7, New York, USA.

Benson, E.E., Lynch, P.T., Jones, J. (1992) Variation in free radical damage in rice cell suspensions with different embryogenic potentials. Planta 188: 296-305. ISSN: 00320935

Borras, O.; Santos, R.; Matos, A.; Cabral, R.; Arzola, M. (2001) A first attempt to use a Fusarium subglutinans culture filtrate for the selection of pineapple cultivars resistant to fusariose disease. Plant Breed. 120: 435-438. ISSN: 0179-9541

Chen, T.H.H.; Kartha, K.K.; Constable, F.; Gusta, L.V. (1984) Freezing characteristics of cultured Catharanthus roseus (L.) G. Don cells trated with dimethylsulfoxide and sorbitol in relation to cryopreservation. Plant Physiol. 75, 720-725. ISSN: 0032-0889

Chowdhury, M.K.U. \& Vasil, I.K. (1993) Molecular analysis of plant regenerated from embryogenic cultures of hybrid sugarcane cultivars (Saccharum spp.). Theor. Appl. Genet 86, 181-188. ISSN: 0040-5752

Côte, F.X.; Goué, O.; Domergue, R.; Panis, B.; Jenny, C. (2000) In-field behavior of banana plants (Musa spp.) obtained after regeneration of cryopreserved embryogenic cell suspensions. Cryo-Letters 21, 19-24. ISSN: 0143-2044

Cyr, D.R. (2000) Cryopreservation: roles in clonal propagation and germplasm conservation of conifers. In: Cryopreservation of tropical plant germplasm - Current research progress and applications. Engelmann, F.; Takagi, H., Eds. (261-268) Tsukuba: JIRCAS; Rome: IPGRI. ISBN 92-9043-428-7, Rome, Italy.

Duan, X.Q.; Hall, J.A.; Nikaido, H.; Quicho, F.A. (2001) Crystal structures of the maltodextrin/maltose-binding protein complexed with reduced oligosaccharides: flexibility of tertiary structure and ligand binding. Journal of Molecular Biology 306:5, (9 March 2001), 1115-1126. ISSN: 0022-2836

Dumet, D.; Block,W.; Worland, R.; Reed, B.M.; Benson, E.E. 2000. Profiling cryopreservation protocols for Ribes ciliatum using differential scanning calorimetry. Cryo-Letters 21: 367-378. ISSN: 0143-2044 
Eksomtramage T.; Paulet F.; Guiderdoni E.; Glaszmann J.C.; Engelmann F. (1992) Development of a cryopreservation process for embryogenic calluses of a commercial hybrid of sugarcane (Saccharum sp.) and application to different varieties. Cryo-Letters 13, 239-52. ISSN: 0143-2044.

Engelmann, F. \& Takagi, H. Eds. (2000) Cryopreservation of tropical plant germplasm - Current research progress and applications. Tsukuba: JIRCAS; Rome: IPGRI; ISBN 92-9043-4287, Rome, Italy.

Engelmann, F. (1997) Importance of desiccation for the cryopreservation of recalcitrant seed and vegetatively propagated species. Plant Genet. Res. Newsletter 112, 9-18. ISSN: 1020-3362

Engelmann, F. (1997) In vitro conservation methods. In: Biotechnology and Plant Genetic Resources Conservation and Use. BV Ford-Lloyd, JH Newburry \& JA Callow (Eds). pp. 119-161. ISBN: 0851991424, CABI, Wallingford.

Engelmann, F. (2000) Importance of cryopreservation for the conservation of plant genetic resources. In: Cryopreservation of tropical plant germplasm - Current research progress and applications. Engelmann, F.; Takagi, H., Eds. (8-20) Tsukuba: JIRCAS; Rome: IPGRI; ISBN 92-9043-428-7, Rome, Italy.

Engelmann, F. (2004) Plant cryopreservation: progress and prospects. In Vitro Cell Dev Biol Plant 40, 427-433. ISSN 1054-5476

Engelmann, F. (2010) Use of biotechnologies for the conservation of plant biodiversity. In Vitro Cell Dev Biol Plant DOI 10.1007/s11627-010-9327-2, ISSN 1054-5476

Engelmann, F. (2011) Cryopreservation of Embryos: An Overview. In: Plant Embryo Culture: Methods and Protocols, Methods in Molecular Biology. Trevor, A.T. \& Yeung, E.C. Eds. Vol. 710, DOI 10.1007/978-1-61737-988-8_13, ISBN 978-1-61737-987-1, Springer Science+Business Media, LLC 2011.

Esterbauer, H.; Zollner, H.; Schauer, R.J. (1988) Hydroxyalkenals: Citotoxics products of lipid peroxidtion. In: ISI Atlas of Sciences: Biochemistry 311-317. ISBN. 0-941708-00-4

Fabre, J. \& Dereuddre, J. (1990) Encapsulation-dehydration: A new approach to cryopreservation of Solanum shoot tips. Cryo-Letters 11, 413 - 426. ISSN: 0143-2044

Fahy, G.M.; Lilley, T.H.; Linsdell, H.; Douglas, M.S.J.; Meryman, H.T. (1990) Cryoprotectant toxicity and cryoprotectant toxicity reduction: in search of molecular mechanisms. Cryobiology 27(3), (June 1990), 247-68. ISSN: 0011-2240

Fahy, G.M.; McFarlane, D.R.; Angell, C.A.; Meryman, H.T. (1984) Vitrification as an approach to cryopreservation. Cryobiology, 21(4), (August 1984), 407-426. ISSN: 0011-2240

Feher, A.; Pasternak, T.P.; Dudits, D. (2003) Transition of somatic cells to an embryogenic state. Plant Cell, Tissue and Organ Culture 74, 201-228. ISSN: 0167-6857

Feldmann, P.; Sapotille, J.; Gredoire, P.; Rott, P. (1994) Micropropagation of sugarcane. In: In vitro culture of tropical plants. C Teisson (ed). CIRAD, ISBN 2-87614-162-0, Montpellier, pp. 15-17.

Finkle, B.J. \& Ulrich, J.M. (1979) Effect of cryoprotectants in combination on the survival of frozen sugarcane cells. Plant Physiology 63, 598-604. ISSN: 0032-0889

Finkle, B.J. \& Ulrich, J.M. (1982) Cryoprotectant removal as a factor in the survival of frozen rice and sugarcane cells. Cryobiology 19(3), (June 1982) 329-335. ISSN: 0011-2240 
Finkle, B.J. ; Zavala, M.E.; Ulrich, J.M. (1985) Cryoprotective compounds in the viable freezing of plant tissues. In: Cryopreservation of plant cells and organs. Kartha, K.K. Ed., 243-267, ISBN 0-8493-6102-8, CRC Press, Boca Raton. USA.

Fleck, R.A.; Day, J.G.; Clarke, K.J.; Benson, E.E. (1999) Elucidation of the metabolic and structural basis for the cryopreservation recalcitrance of Vaucheria sessilis, Xanthophyceae. Cryo-Letters 20, 271-282. ISSN: 0143-2044

Flynn, L. \& Anderlini, T. (1990) Disease incedence and yield performance of tissue culturegenerated seed cane over the crop cycle in Lousiana. Journal of American Society of Sugar Cane Technologists 10, 113. ISSN 1991-8178

Gnanapragasam, S. \& Vasil, I.K. (1990) Plant regeneration from a cryopreserved embryogenic cell suspension of a commercial sugarcane hybrid (Saccharum sp.) Plant Cell Rep. 9, 419-423. ISSN: 0721-7714

Gnanapragasam, S. \& Vasil, I.K. (1992) Cryopreservation of immature embryos, embryogenic callus and cell suspension cultures of gramineous species. Plant Science 83, 205-215. ISSN: 0168-9452

Gonzalez-Arnao, M.T.; Engelmann F.; Huet C.; Urra C (1993) Cryopreservation of encapsulated apices of sugarcane: Effect of freezing procedure and histology. CryoLetters 14, 303-308. ISSN: 0143-2044

Gonzalez-Arnao, M.T.; Engelmann. F.; Urra-Villavicencio. C.; Morenza, M.; Rios, A. (1998a) Cryopreservation of citrus apices using the encapsulation-dehydration technique. Cryo-Letters 19,177-182. ISSN: 0143-2044

Gonzalez-Arnao, M.T.; Juarez, J.; Ortega, C.; Navarro, L.; Duran-Vila, N. (2003) Cryopreservation of ovules and somatic embryos of citrus using the encapsulationdehydration technique. Cryo-Letters 24 (2), 85-94. ISSN: 0143-2044

Gonzalez-Arnao, M.T.; Moreira, T.; Urra, C. (1996) Importance of pregrowth with sucrose and vitrification for the cryopreservation of sugarcane apices using encapsulationdehydration. Cryo-Letters 27, 141-148. ISSN: 0143-2044

Gonzalez-Arnao, M.T.; Ravelo, M.M.; Urra-Villavicencio, C.; Martinez-Montero, M.M.; Engelmann, F. (1998b) Cryopreservation of pineapple (Ananas comosus) apices. Cryo-Letters 19, 375-382. ISSN: 0143-2044

Gonzalez-Arnao, M.T.; Urra, C.; Engelmann, F.; Ortiz, R.; de la Fe, C. (1999) Cryopreservation of encapsulated sugarcane apices: Effect of storage temperature and storage duration. Cryo-Letters 20, 347-352. ISSN: 0143-2044

Grune, T.; Michel, P.; Sitte, N.; Eggert, W.; Albrecht-Nebe, H.; Esterbauer, H.; Siems, W.G. (1997) Increased levels of 4-hydroxynonenal modified proteins in plasma of children with autoimmune diseases. Free Radical Biology and Medicine 23 (3), (November 1996), 357-360. ISSN: 0891-5849

Guy, C. (1999) Molecular responses of plants to cold shock and cold acclimation. J Mol Microbiol Biotechnol. 1(2), 231-242. ISSN: 1464-1801

Harding, K. (1999) Stability assessments of conserved plant germplasm. In: Plant Conservation \& Biotechnology. Chapt. 7. Benson, E.E. Ed., pp. 97-107, Taylor and Francis Ltd., ISBN 0-7484-0746-4, London, UK.

Harding, K. (2004) Genetic integrity of cryopreserved plant cells: A review. Cryo-Letters 25, 3-22. ISSN: 0143-2044 
Harding, K.; Johnston, J.; Benson, E. E. (2005) Plant and algal cell cryopreservation: issues in genetic integrity, concepts in 'Cryobionomics' and current European applications. In: Contributing to a Sustainable Future. Benett, I.J.; Bunn, E.; Clarke, H.; McComb, J. A., Eds., (112-119) Proc. Australian Branch IAPTC \& B, Perth, Western Australia.

Ishikawa, M.; Ide H.; Price, W.S.; Arata, Y.; Kitashima, T. (2000) Freezing behaviors in plant tissues as visualized by NMR microscopy and their regulatory mechanisms. In: Cryopreservation of tropical plant germplasm - Current research progress and applications. Engelmann, F.; Takagi, H., Eds. (22-35) Tsukuba: JIRCAS; Rome: IPGRI. ISBN 929043-428-7, Rome, Italy.

Jackson, W.; Wagnespack, H.; Richard, C.; Garrison, D.; Lester, W. (1990) CP65-357 Kleentek test in Lousiana. Journal of the American Society of Sugar Cane Technologist 21, 10-13. ISSN 1991-8178

Jian, L.C.; Sun, D.L.; Sun, L.H. (1987) Sugarcane callus cryopreservation. In: Plant cold hardiness. Li, P.H. Ed., 323-337, Alan R. Liss, Inc., ISBN 0-8451-1084-8, New York.

Jiménez, E.; Pérez, J.; Gil, V.; Herrera, J.; García, Y.; Alfonso, E. (1995) Sistemas para la propagación de caña de azúcar. In: Avances de la Biotecnología Moderna Estrada M, Riego E, Limonta E, Tellez P, Fuentes J (Eds).. Elfos Scientiae. Cuba 3:11.2

Jin, H.; Hartman, G.L.; Nickell, C.D.; Widholm, J.M. (1996) Phytotoxicity of culture filtrate from Fusarium solani, the causal agent of Soybean Sudden Death Syndrome. Plant Dis. 80: 922-927. ISSN: 0191-2917

Joyce, S.M.; Cassells A.C.; Jain, M.S. (2003) Stressand aberrant phenotypes in vitro culture. Plant Cell Tissue and Organ Culture 74, 103-21. ISSN:0167-6857

Kaczmarczyk, A.; Shvachko, N.; Lupysheva, Y.; Hajirezaei, M.R.; Keller, E.R.J. (2008) Influence of altering temperature preculture on cryopreservation results for potato shoot tips. Plant Cell Rep. 27: 1551-1558. ISSN: 0721-7714

Kartha, K.K. \& Engelmann F. (1994) Cryopreservation and germplasm storage. In: Plant cell and tissue culture. Vasil, I.K. \& Thorpe, T.A. Eds. (195-230) Kluwer, ISBN 978-07923-2493-5, Dordrecht.

Kartha, K.K.; Fowke, L.C.; Leung, N.L.; Caswell, K.L.; Hakman I. (1988) Induction of somatic embryos and plantlets from cryopreserved cell cultures of white spruce (Picea glauca). J. Plant Physiol 132, 529-39. ISSN: 0176-1617

Kaur, G.; Singh, U.S.; Garg, G.K. (1987) Mode of action of toxin isolated from Fusarium oxysporum f. sp. ciceri. Indian Phytopathol 40: 76-84. ISSN 0367-973X

Kinoshita, K.; Li, S.J.; Yamazaki, M. (2001) The mechanism of the stabilization of the hexagonal II (HII) phase in PE membranes in the presence of low concentrations of dimethyl sulfoxide. Eur Biophysics J 30, 207-220. ISSN 0175-7571

Klimazewska, K.; Ward, C.; Cheliak, W.M. (1992) Cryopreservation and plant regeneration from embryogenic cultures of larch (Larix $\mathrm{x}$ eurolepis) and black spruce (Picea mariana). J Exp Bot 43, 73-79. ISSN: 0022-0957

Krishnamurthy, K.V.; Kishnaraj, R.; Chozavendam, R.; Samuel, C.F. (2000) The programme of cell death in plants and animals. A comparison. Curr Sci 79, 1169-1181. ISSN: 0011-3891

Krishnaraj, S. \& Vasil, I.K. (1995) Somatic embryogenesis in herbaceous monocots. In: In vitro embryogenesis in plants. Current Plant Science and Biotechnology in Agriculture, 
Thorpe, T.A. Ed. Kluwer Academic Publishers; 20, 417-469. ISBN: 0-7923-3149-4, Dordrecht, Netherlands.

Kristensen, M.M.H.; Find, J.I.; Floto, F.; Moller, J.D.; Norgaard, J.V.N.; Krogstrup, P. (1994) The origin and development of somatic embryos following cryopreservation of an embryogenic suspension culture of Picea sitchensis. Protoplasma 182, 65-70. ISSN: 0033-183X

Leprince, O.; Hendry, G.A.F.; McKersie, B.D. (1993) The mechanisms of desiccation tolerance in developing seeds. Seed Science Research, 3: 231-246. ISSN: 0960-2585

Lorenzo, J.C.; Ojeda, E.; Espinosa, A.; Borroto, C. (2001) Field performance of temporary bioreactor-derived sugarcane plants. In Vitro Cell Dev. Biol.-Plant. 37, 803-806. ISSN 1054-5476

Lourens, A.G. \& Martin, F.A. (1987) Evaluation of in vitro propagated sugarcane hybrids for somaclonal variation. Crops Science 27, 793-796. ISSN: 0011-183X

Lunn, J.E. \& MacRae, E. (2003) New complexities in the synthesis of sucrose. Current Opinion in Plant Biology 6, 208-224. ISSN: 1369-5266

Luo, J. \& Reed, B.M. (1997) Abscisic acid-responsive protein bovine serum albumin and proline pretreatments improve recovery of in vitro currant shoot tips and callus cryopreserved by vitrification. Cryobiology 34:240-250. ISSN: 0011-2240

Lynch, P.T.; Benson, E.E.; Harding, K. (2007) Climate change: the role of ex situ and cryoconservation in the future security of economically important, vegetatively propagated plants. Journal of Horticultural Science E Biotechnology 82 (2), 157-160. ISSN: 1462-0316

Maddox, A.D.; Gonsalves, F.; Shields, R. (1983) Successful preservation of suspension cultures of three Nicotiana species at the temperature of liquid nitrogen. Plant Science Letters 28, 157-162. ISSN: 0304-4211

Martinez-Montero, M.E.; Gonzalez-Arnao, M.T.; Borroto-Nordelo, C.; Puentes-Diaz, C.; Engelmann, F. (1998) Cryopreservation of sugarcane embryogenic callus using a simplified freezing process. Cryo-Letters, 19, 171-176. ISSN: 0143-2044

Martinez-Montero, M.E.; Lorenzo, J.C.; Ojeda, E.; Quiñones, J.; Mora, N.; Sánchez, M.; Iglesias, A.; Martínez, J.; Castillo, R. (2006) Methodology for the cryopreservation of calli with embryogenic structures for the culture of sugarcane. Biotecnología Aplicada 23(4), 360-375. ISSN: 1027-2852

Martínez-Montero, M.E.; Martínez, J.; Castillo, R.; Engelmann, F.; González-Arnao, M.T.; (2005) Cryopreservation of pineapple (Ananas comosus (L.) Merr) apices and calluses. Acta Hort. (ISHS) 666, 127-131. (ISSN 0567-7572

Martinez-Montero, M.E.; Martinez, J.; Engelmann, F. (2008) Cryopreservation of sugarcane somatic embryos. Cryo-Letters, 29(3), 229-242. ISSN: 0143-2044

Martinez-Montero, M.E.; Mora, N.; Quiñones, J.; Gonzalez-Arnao, M.T.; Engelmann, F.; Lorenzo, J.C. (2002a) Effect of cryopreservation on the structural and functional integrity of cell membranes of sugarcane embryogenic calluses. Cryo-Letters 23, 237244. ISSN: 0143-2044

Martinez-Montero, M.E.; Ojeda, E.; Espinosa, A.; Sánchez, M.; Castillo, R.; Gonzalez-Arnao, M.T.; Engelmann, F.; Lorenzo, J.C. (2002b) Field performance of cryopreserved callus-derived sugarcane plants. Cryo-Letters 23(1), 21-26. ISSN: 0143-2044 
Matsumoto T, Sakai A, Takahashi C y Yamada K (1995) Cryopreservation of in vitro-grown apical meristems of wasabi (Wasabia japonica) by encapsulation-vitrification method. CryoLetters. 16: 189-196. ISSN: 0143-2044

Matsumoto, T.; Sakai, A.; Takahashi, C.; Yamada, K. (1995) Cryopreservation of in vitrogrown apical meristems of wasabi (Wasabia japonica) by encapsulation-vitrification method. Cryo-Letters 16, 189-196. ISSN: 0143-2044

McGann, L.E. \& Walterson, M.L. (1987) Cryoprotection by dimehyl sulfoxide and dimethyl sulfone. Cryobiology 24(1), (February 1987), 11-16. ISSN: 0011-2240

Merkle, S.A.; Parrot, W.A.; Flinn, B.S. (1995) Morphogenicaspects of somatic embryogenesis. In: In vitro embryogenesis in plants. Current Plant Science and Biotechnology in Agriculture, Thorpe, T.A. Ed. Kluwer Academic Publishers; 20, 155-204. ISBN: 07923-3149-4, Dordrecht, Netherlands.

Mittler, R.; Vanderauwera, S.; Gollery, M.; Van Breusegem, F. (2004) Reactive oxygen gene network of plants. Trends Plant Sci. 9, 490-498. ISSN: 1360-1385

Mix-Wagner, G.; Conner, A.J.; Cross, R.J. (2000) Survival and recovery of asparagus shoot tips after cryopreservation using the "droplet" method. New Zeal. J. Crop E Hort Sci., 28, 283-287. ISSN: 0114-0671

Murashige, T.; Skoog, F. (1962) A revised medium for rapid growth and bioassays with tobacco tissue cultures. Physiol. Plant. 15: 473-497. ISSN: 0031-9317

Nieves, N.; Martinez-Montero, M.E.; Castillo, R.; Blanco, M.A.; González-Olmedo, J.L. (2001) Effect of abscisic acid and jasmonic acid on partial desiccation of encapsulated somatic embryos of sugarcane. Plant Cell Tissue and Organ Culture 65, 15-21. ISSN: 0167-6857

Niu, D.K.; Wang, M.G.; Wang, Y.F. (1997) Plant cellular osmotica. Acta Biotheoretica 45(2), 161-169. ISSN: 0001-5342

Panis, B. \& Lambardi, M. (2006) Status of cryopreservation technologies in plants (crops and forest trees). In: The role of Biotechnology in Exploring and Protecting Agricultural Genetic Resources, Ruane, J. \& Sonnino, A. Eds. (61-78) FAO, ISBN 92-5-105480-0, Rome, Italy.

Panis, B. \& Thinh, N.T. (2001) Cryopreservation of Musa germplasm, INIBAP Technical Guideline 5. Escalant, J.V. \& Sharrock, S. Eds., International Network for the Improvement of Banana and Plantain, ISBN: 2-910810-45-3, Montpellier, France. IPGRI, Rome, Italy.

Panis, B.; Piette, B.; Swennen, R. (2005) Droplet vitrification of apical meristems: a cryopreservation protocol applicable to all Musaceae. Plant Sci. 168, 45-55. ISSN: 0168-9452

Parsegian, V.A.; Rand, R.P.; Rau, D.C. (1995) Macromolecules and water: Probing with osmotic stress. In: Methods in Enzymology: Energetics of Biological Macromolecules. Johnson, M.L. \& Ackers, G.K. Eds. 259, (43-94), ISBN: 978-0-12-182160-9, Academic Press Inc., New York.

Parsegian, V.A.; Rand, R.P.; Rau, D.C. (2000) Osmotic stress, crowding, preferential hydration, and binding: A comparison of perspectives. Proceedings of the National Academy of Sciences USA, 3987-3992. ISSN-0027-8424 
Paulet, F.; Engelmann, F.; Glaszmann, J.C. (1993) Cryopreservation of apices of in vitro plantlets of sugarcane (Saccharum sp. hybrids) using encapsulation-dehydration. Plant Cell Rep. 12, 525-529. ISSN: 0721-7714

Pena, M. \& Stay, M. (1997) Ventajas de la propagacion in vitro. Canaveral 3(24), 473-497. ISSN: 1026-0781

Pérez, J.N.; Jiménez, E.; Gómez, R. (1999) Mejora genética de la caña de azúcar mediante la inducción de mutaciones y la selección in vitro. In: Biodiversidad y Biotecnología de la Caña de Azúcar. A Arencibia \& MT Cornide (eds.). pp. 79-92, ISBN: 959-235-015-9, Elfos Scientiae, Cuba.

Rabe, E. and C. J. Lovatt (1984). De novo arginine biosynthesis in leaves of phosphorusdeficient Citrus and Poncirus species. Plant Physiology 76(3): 747-752. ISSN: 00320889

Rasmussen, P.H.; Jorgensen, B. \& Nielsen, J. (1997) Cryoprotective properties of proline in cod muscle studied by differential scanning calorimetry. Cryo-Letters 18, 293-300. ISSN: 0143-2044

Reed, B.M. (2001) Implementing cryogenic storage of clonally propagated plants. CryoLetters 22, 97-104. ISSN: 0143-2044

Reinhoud, P.J.; Van Iren, F.; Kijne, J.W. (2000) Cryopreservation of undifferentiated plant cells. In: Cryopreservation of tropical plant germplasm - Current research progress and applications. Engelmann, F.; Takagi, H., Eds. (91-102) Tsukuba: JIRCAS; Rome: IPGRI. ISBN 92-9043-428-7, Rome, Italy.

Ruan, K.; Xu, Ch.; Li, T.; Li, J.; Lange, R.; Balny, C. (2003) The thermodynamic analysis of protein stabilization by sucrose and glycerol against pressure-induced unfolding: The typical example of the 33-kDa protein from spinach photosystem II. European Journal of Biochemistry 270, 1654-1661. ISSN: 0014-2956

Rudolph, A.S. \& Crowe, J.H. (1985) Membrane stabilization during freezing: the role of two natural cryoprotectants, trehalose and proline. Cryobiology 22, 367-377. ISSN: 00112240

Sakai, A. \& Engelmann, F. (2007) Vitrification, encapsulation-vitrification and dropletvitrification: a review. Cryo-Letters 28, 151-172. ISSN: 0143-2044

Sakai, A.; Kobayashi, S.; Oiyama, I. (1990) Cryopreservation of nucellar cells of navel orange (Citrus sinensis Osb. var brasiliensis Tanaka) by vitrification. Plant Cell Rep. 9, 30-33. ISSN: 0721-7714

Sakai, A.; Matsumoto, T.; Hirai, D.; Charoensub, R. (2002) Survival of tropical apices cooled to $-196^{\circ} \mathrm{C}$ by vitrification. In: Plant cold hardiness, gene regulation and genetic engineering. Li, P.H.; Palva, E.T. Eds., 109-119, Kluwer Academic/Plenum Publishers, ISBN: 0306472864, New York.

Schäfer-Menuhr, A.; Schumacher, H.M.; Mix-Wagner, G. (1997) Long-term storage of old potato varieties by cryopreservation of shoot-tips in liquid nitrogen. Plant Genet. Res. Newsletter 111, 19-24. ISSN: 1020-3362

Semenova, M.G.; Antipova, A.S.; Belyakova, L.E. (2002) Food protein interactions in sugar solutions. Current Opinions in Colloid Interface Science 7, 438-444. ISSN: 1359-0294

Spiteller, G. (1996) Enzymic lipid peroxidation-a consequence of cell injury? Free Radical Biology and Medicine 21(7), 1003-1009. ISSN: 0891-5849 
Stanley, C.; Krueger, S.; Parsegian, V.A.; Rau, D.C. (2008) Protein structure and hydration probed by SANS and osmotic stress. Biophysical Journal 94, 2777-2789, (April 2008), ISSN: 0006-3495

Sun, W.Q. (1999) State and phase transition behaviors of Quercus rubra seed axes and cotyledonary tissues: relevance to the desiccation sensitivity and cryopreservation of recalcitrant seeds. Cryobiology, 38(4), (June 1999), 372-385. ISSN: 0011-2240

Swan, T.W.; O’Hare, D.; Gill, R.A.; Lynch, P.T. (1999) Influence of preculture conditions on the post-thaw recovery of suspension cultures of Jerusalem artichoke (Helianthus tuberosus L.). Cryo-Letters 20, 325-336. ISSN: 0143-2044

Swartz, H.J. (1991) Post culture behaviour: genetic and epigenetic effects and related problems. In: Micropropagation. Technology and Application. PC Debergh \& RH Zimmermann (eds.). pp. 95-121, Kluwer Academic Publishers, ISBN: 9780792308195, Dordrecht, Netherlands.

Tapia, R.; Castillo, R.; Blanco, M.A.; González, J.L.; Sánchez, M.; Rodríguez, Y. (1999) Induction, maduration and encapsulation of sugarcane somatic (Saccharum spp) cv CP5243. Biotecnología Aplicada 16, 20-23. ISSN: 1027-2852

Taylor, P.; Ko, H.; Adkins, S.; Rathus, C.; Birch, R. (1992) Establishment of embriogenic callus and high protoplast yielding suspension cultures of sugarcane (Saccharum spp. hybrids) Plant Cell Tissue and Organ Culture 28: 69-78. ISSN: 0167-6857

Tetteroo, F.A.A. (1996) Desiccation tolerance of somatic embryoids. PhD Thesis, Wageningen Agricultural University, The Nederlands. ISBN 90-5485-517-7

Thierry, C.; Florin, B.; Petiard, V. (1999) Changes in protein metabolism during the acquisition of tolerance to cryopreservation of carrot somatic embryos. Plant Physiol. Biochem. 37, 145-154. ISSN: 0981-9428

Thinh, N.T.; Takagi, H.; Yashima, S. (1999) Cryopreservation of in vitro-grown shoot tips of banana (Musa spp.) by vitrification method. Cryo-Letters 20(3), 163-174. ISSN: 01432044

Thomashow, M.F. (1999) Plant cold acclimation: Freezing tolerance genes and regulatory mechanisms. Annu. Rev. Plant Physiol. Plant Mol. Biol 50, 571-599. ISSN:1040-2519

Timasheff, S.N. (1993) The Control of Protein Stability and Association by Weak Interactions with Water: How Do Solvents Affect These Processes? Annual Review of Biophysical and Biomolecular Structure 22, 67-97, (June 1993), ISSN: 1056-8700

Turner, S.; Senaratna, T.; Touchell, D.; Bunn, E.; Dixon, K.; Tan, B. (2001) Stereochemical arrangement of hydroxyl groups in sugar and polyalcohol molecules as an important factor in effective cryopreservation. Plant Science 160, 489-497. ISSN: 0168-9452

Turner, S.R.; Krauss, S.L.; Bunn, E. Senaratna, T.; Dixon, K.W.; Tan, B.; Touchell, D.H. (2001) Genetic fidelity and viability of Anigozanthos viridis following tissue culture, cold storage and cryopreservation. Plant Science 161, 1099-1106. ISSN: 0168-9452

Tyler, N.; Stushnoff, C.; Gusta, L.V. (1988) Freezing of water in dormant vegetative apple buds in relation to cryopreservation. Plant Physiol 87, 201-205. ISSN: 0032-0889

Ulrich, J.M.; Finkle, B.J.; Moore, P.H. (1984) Frozen preservation of cultured sugarcane cells. SugarCane 3, 11-14. 
Ulrich, J.M.; Finkle, B.J.; Moore, P.H.; Ginoza H. (1979) Effect of a mixture of cryoprotectants in attaining liquid nitrogen survival of callus culturesof a tropical plant. Cryobiology 16, 550-556. ISSN: 0011-2240

Verleysen, H.; Samyn, G.; Van Bockstaele, E.; Debergh, P. (2004) Evaluation of analytical techniques to predict viability fter cryopreservation Plant Cell Tissue and Organ Culture 77, 11-21. ISSN: 0167-6857

Volk, G.M. \& Walters, C. (2006) Plant vitrification solution 2 lowers water content and alters freezing behaviour in shoot tips during cryoprotection. Cryobiology 52, 48-61. ISSN: 0011-2240

Watanabe, K.; Kuriyama, A.; Kawai, F.; Kanamori, M. (1999) Effect of cryoprotectant treatment and post-thaw washing on the survival of cultured rice (Oryza sativa L.) cells after cryopreservation. Cryo-Letters 20, 377-382. ISSN: 0143-2044

Withers, L.A. \& King, P.J. (1980) A simple freezing unit and routine cryopreservation method for plant cell cultures. Cryo-Letters 1, 213-220. ISSN: 0143-2044

Withers, L.A. (1985) Cryopreservation of cultures plant cells and protoplasts. In: Cryopreservation of plant cells and organs. Kartha, K.K. Ed., 243-267, CRC Press, ISBN 0-8493-6102-8, Boca Raton. USA.

Yang, M.H. \& Schaich, K.M. (1996) Factors affecting DNA damage caused by lipid hydroperoxides and aldehydes. Free Radical Biology and Medicine 20(2), (July 1995), 225-236. ISSN: 0891-5849

Yoshida, S.; Hattanda, Y.; Suyama, T. (1993) Variationsin chilling sensitivity of suspension cultured cells of mung bean (Vigna radiata (L.) Wilczek) during the growth cycle. Plant Cell Physiology 34, 673-679. ISSN 0032-0781 


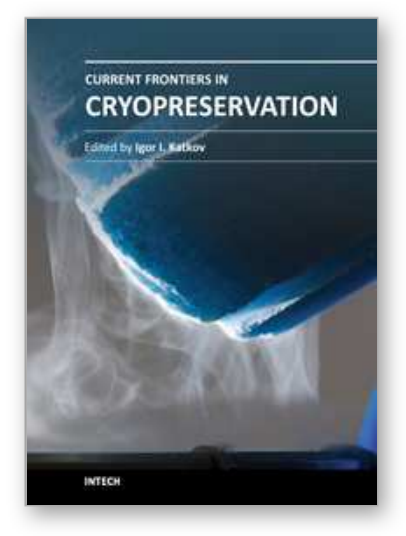

\author{
Current Frontiers in Cryopreservation \\ Edited by Prof. Igor Katkov
}

ISBN 978-953-51-0302-8

Hard cover, 462 pages

Publisher InTech

Published online 14, March, 2012

Published in print edition March, 2012

Almost a decade has passed since the last textbook on the science of cryobiology, Life in the Frozen State, was published. Recently, there have been some serious tectonic shifts in cryobiology which were perhaps not seen on the surface but will have a profound effect on both the future of cryobiology and the development of new cryopreservation methods. We feel that it is time to revise the previous paradigms and dogmas, discuss the conceptually new cryobiological ideas, and introduce the recently emerged practical protocols for cryopreservation. The present books, "Current Frontiers in Cryobiology" and "Current Frontiers in Cryopreservation" will serve the purpose. This is a global effort by scientists from 27 countries from all continents and we hope it will be interesting to a wide audience.

\title{
How to reference
}

In order to correctly reference this scholarly work, feel free to copy and paste the following:

Marcos Edel Martinez-Montero, Maria Teresa Gonzalez Arnao and Florent Engelmann (2012).

Cryopreservation of Tropical Plant Germplasm with Vegetative Propagation - Review of Sugarcane (Saccharum spp.) and Pineapple (Ananas comusus (L.) Merrill) Cases, Current Frontiers in Cryopreservation, Prof. Igor Katkov (Ed.), ISBN: 978-953-51-0302-8, InTech, Available from:

http://www.intechopen.com/books/current-frontiers-in-cryopreservation/cryopreservation-of-tropical-plantgermplasm-with-vegetative-propagation-review-of-sugarcane-sacchar

\section{INTECH}

open science | open minds

\section{InTech Europe}

University Campus STeP Ri

Slavka Krautzeka 83/A

51000 Rijeka, Croatia

Phone: +385 (51) 770447

Fax: +385 (51) 686166

www.intechopen.com

\section{InTech China}

Unit 405, Office Block, Hotel Equatorial Shanghai

No.65, Yan An Road (West), Shanghai, 200040, China

中国上海市延安西路65号上海国际贵都大饭店办公楼 405 单元

Phone: +86-21-62489820

Fax: $+86-21-62489821$ 
(C) 2012 The Author(s). Licensee IntechOpen. This is an open access article distributed under the terms of the Creative Commons Attribution 3.0 License, which permits unrestricted use, distribution, and reproduction in any medium, provided the original work is properly cited. 